\title{
Solid Phase Characterization of Tank 241-AY-102 Annulus Space Particulate
}

\author{
G. A. Cooke \\ Washington River Protection Solutions LLC
}

Date Published

January 2013

Prepared for the U.S. Department of Energy

Office of River Protection

Contract No. DE-AC27-08RV14800 
TRADEMARK DISCLAIMER

Reference herein to any specific commercial product, process,

or service by trade name, trademark, manufacturer, or

otherwise, does not necessarily constitute or imply its

endorsement, recommendation, or favoring by the United

States Government or any agency thereof or its contractors or subcontractors.

This report has been reproduced from the best available copy.

Printed in the United States of America 


\section{Table of Contents}

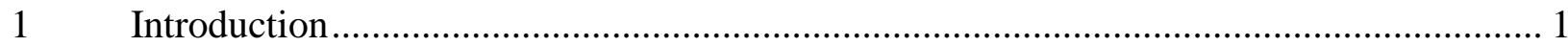

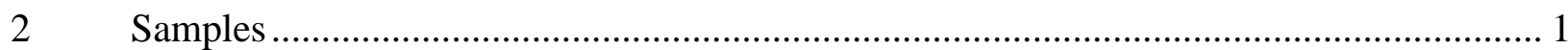

2.1 Solid Phase Characterization Analysis of Tank 241-AY-102 Annulus-1 Tape Samples S12R000485, S12R000487, and S12R000488 …………………………………...... 2

2.2 Solid Phase Characterization Analysis of 2AY-12-ANU1 Samples S12T021101 (S12R000514) White and S12T021200 (S12R000516) Black .......................................... 8

2.3 Solid Phase Characterization Analysis of 2AY-12-ANU3 (S12T021354/S12R000529) and 2AY-12-ANU5 (S12T021355/S12R000531) ………………………………........ 16

2.4 Solid Phase Characterization Analysis of 2AY-12-ANU3A (S12T021346/S12R000533)

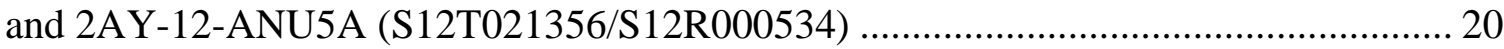

2.4.1 Solid Phase Characterization of Sample 2AY-12-ANU3A …………………………….... 24

2.4.2 Solid Phase Characterization of Sample 2AY-12-ANU5A …………………………….... 28

3 Discussion ........................................................................................................ 33

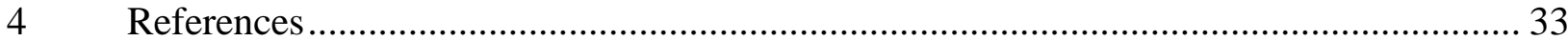

Appendix A SAMPLE BREAKDOWN DIAGRAMS ……………………............. A-i

\section{List of Figures}

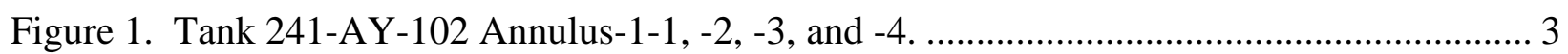

Figure 2. Secondary Electron Image and Energy Dispersive X-ray Spectrometer Spectrum from Tape Samples.

Figure 3. Optical (left), Backscatter Electron (right) Images of Paint Flake, Energy Dispersive $\mathrm{X}$-ray Spectrometer Spectrum from Area in Yellow Box.

Figure 4. Secondary Electron Image and Energy Dispersive X-ray Spectrometer Spectrum of Area Boxed in Yellow.

Figure 5. Secondary Electron Image and Energy Dispersive X-ray Spectrometer Spectrum from Tape Samples.

Figure 6. Secondary Electron Image and Energy Dispersive X-ray Spectrometer Spectrum from Tape Samples.

Figure 7. Secondary Electron Image and Energy Dispersive X-ray Spectrometer Spectrum from Tape Samples.

Figure 8. Secondary Electron Image and Energy Dispersive X-ray Spectrometer Spectrum from Tape Samples.

Figure 9. Secondary Electron Image and Energy Dispersive X-ray Spectrometer Spectrum from

Tape Samples.

Figure 10. Secondary Electron Image and Energy Dispersive X-ray Spectrometer Spectrum

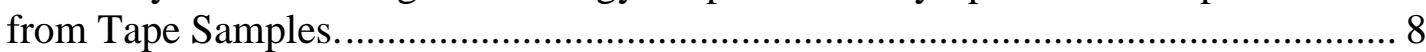

Figure 11. Hot Cell Photo of 2AY-12-ANU1 Samples....................................................... 9

Figure 12. X-ray Diffraction Pattern for Sample S12R000514 ................................................ 10

Figure 13. Scanning Electron Microscopy Image and Energy Dispersive X-ray Spectrometry Spectrum of Sample S12R000514 (2AY-12-ANU1 White). 
Figure 14. Scanning Electron Microscopy Image and Energy Dispersive X-ray Spectrometry Spectrum of Sample S12R000514 (2AY-12-ANU1 White).

Figure 15. Scanning Electron Microscopy Image and Energy Dispersive X-ray Spectrometry

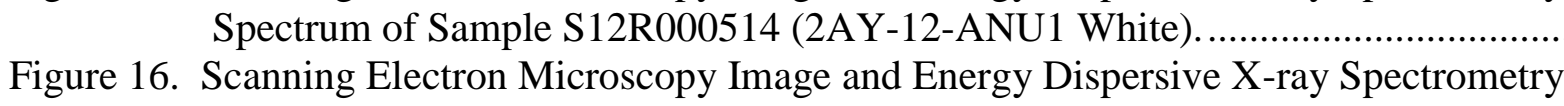
Spectrum of Sample S12R000514 (2AY-12-ANU1 White) .................................. 13

Figure 17. Polarized Light Microscopy Images of Sample S12R000514 (2AY-12-ANU1 White), Crossed Polarizers and Red I Compensator Used.

Figure 18. Scanning Electron Microscopy Image and Energy Dispersive X-ray Spectrometry Spectrum of Sample S12R000516 (2AY-12-ANU1 Black). .................................. 14

Figure 19. Backscatter Electron Image of Sample S12R000516 (2AY-12-ANU1 Black)......... 15

Figure 20. Polarized Light Microscopy Images of Sample S12R000516 (2AY-12-ANU1 Black), Crossed Polarizers and Red I Compensator Used.

Figure 21. Binocular Microscope Photomicrograph of Sample 2AY-12-ANU3, S12R000529. 17

Figure 22. Binocular Microscope Photomicrograph of Sample 2AY-12-ANU5, S12R000531. 17

Figure 23. Scanning Electron Microscopy Image and Energy Dispersive X-ray Spectrometry Spectrum of Sample S12R000531 (2AY-12-ANU5)......................................... 18

Figure 24. X-ray Diffraction Pattern for Sample 2AY-12-ANU5 (S12R000531)................... 19

Figure 25. Scanning Electron Microscopy Image and Energy Dispersive X-ray Spectrometry Spectrum of Sample S12R000531 (2AY-12-ANU5)........................................ 20

Figure 26. Optical Images of 2AY-12-ANU3A. Petri Dish is 2 Inches in Diameter. ............... 21

Figure 27. Optical Images of 2AY-12-ANU5A. Petri Dish is 2 Inches in Diameter............... 21

Figure 28. Aggregate of Salt Crystals Showing Botryoidal Morphology, Sample 2AY-12-

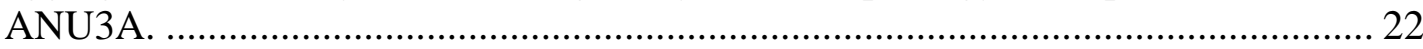

Figure 29. Aggregate of Salt Crystals Showing Blade- or Lath-like Morphology, Sample 2AY-

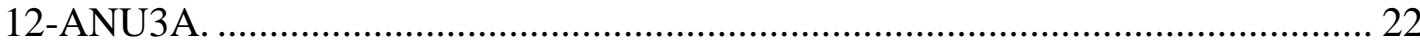

Figure 30. Aggregate of Salt Crystals Showing Glassy and Vesicular Morphology, Sample

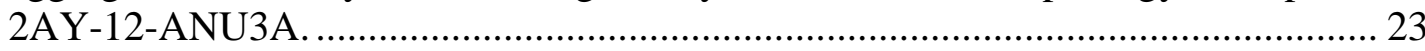

Figure 31. Aggregate of Light and Dark Colored Particulate, Sample 2AY-12-ANU5A........ 23

Figure 32. Sodium Carbonate Laths, Sample 2AY-12-ANU3A (S12R000533)..................... 25

Figure 33. Sodium Fluoride Phosphate, Sample 2AY-12-ANU3A (S12R000533).................. 26

Figure 34. Polarized Light Microscopy Images with Crossed Polarizers and the Red Compensation Plate, Sample 2AY-12-ANU3A (S12R000533).

Figure 35. Minor Potassium Peak in Energy Dispersive X-ray Spectrometry Spectrum, Sample 2AY-12-ANU3A (S12R000533).

Figure 36. Scanning Electron Microscopy Image of Rust/Scale, Sample 12-ANU5A (S12R000534). 29

Figure 37. Scanning Electron Microscopy Image of Quartz, Sample 12-ANU5A (S12R000534).

Figure 38. Scanning Electron Microscopy Image of Potassium Feldspar, Sample 12-ANU5A (S12R000534). 30

Figure 39. Scanning Electron Microscopy Image of Plagioclase Feldspar, Sample 12-ANU5A (S12R000534). 30

Figure 40. Scanning Electron Microscopy Image of Amphibole or Pyroxene, Sample 12ANU5A (S12R000534). 
Figure 41. Scanning Electron Microscopy Image of Sodium-Rich Particulate, Sample 12-ANU5A (S12R000534)....

Figure 42. Scanning Electronic Microscopy Image of Sodium Sulfate Particulate, Sample 12ANU5A (S12R000534).

Figure 43. Polarized Light Microscopy Image with Crossed Polarizers and the Red Compensation Plate, Sample 2AY-12-ANU5A (S12R000534).

\section{List of Tables}

Table 1. Identification of Samples Examined for Solid Phase Characterization......................... 1

Table 2. X-ray Diffraction Results for Sample 2AY-12-ANU3A (S12R000533).

\section{List of Terms}

\section{Acronyms and Abbreviations}

222-S 222-S Laboratory

AY-102 tank 241-AY-102

BEI backscatter electron image

EDS energy dispersive X-ray spectrometer

GEA gamma energy analysis

PLM polarized light microscopy

SEI secondary electron images

SEM scanning electron microscopy or microscope

SPC solid phase characterization

XRD X-ray diffraction

\section{Units}

${ }^{\circ} \mathrm{C}$ degrees centigrade

g gram

in. inch

ml milliliter 


\section{INTRODUCTION}

The Special Analytical Studies Group at the 222-S Laboratory (222-S) examined the particulate recovered from a series of samples from the annular space of tank 241-AY-102 (AY-102) using solid phase characterization (SPC) methods. These include scanning electron microscopy (SEM) using the ASPEX ${ }^{\circledR}{ }^{1}$ scanning electron microscope, $X$-ray diffraction $(\mathrm{XRD})$ using the Rigaku ${ }^{\circledR}{ }^{2}$ MiniFlex X-ray diffractometer, and polarized light microscopy (PLM) using the Nikon ${ }^{3}{ }^{3}$ Eclipse Pol optical microscope. The SEM is equipped with an energy dispersive X-ray spectrometer (EDS) to provide chemical information. Gary A. Cooke conducted the SEM analysis, John Pestovich performed the XRD analysis, and Dr. Heinz Huber performed the PLM examination. The results and conclusion of these analyses are presented here.

\section{SAMPLES}

Samples were received at the lab from four separate sampling events. The materials that were examined for solid phase characterization are identified on Table 1.

Table 1. Identification of Samples Examined for Solid Phase Characterization.

\begin{tabular}{|l|l|l|l|l|}
\hline \multicolumn{1}{|c|}{ Client ID } & Laboratory ID(s) & Date Received & Date Examined & \multicolumn{1}{|c|}{ Comments } \\
\hline AY-102 Annulus-1-1 & S12R000485 & $08-10-2012$ & $08-14-2012$ & Swab sample, Riser 90 \\
\hline AY-102 Annulus-1-3 & S12R000487 & $08-10-2012$ & $08-14-2012$ & Swab sample, Riser 90 \\
\hline AY-102 Annulus-1-4 & S12R000488 & $08-10-2012$ & $08-14-2012$ & Swab sample, Riser 90 \\
\hline 2AY-12-ANU1 white & $\begin{array}{l}\text { S12T021101 } \\
\text { S12R000514 }\end{array}$ & $09-27-2012$ & $10-01-2012$ & $\begin{array}{l}\text { White particles } \\
\text { Floor scraping near Riser 83 }\end{array}$ \\
\hline 2AY-12-ANU1 black & $\begin{array}{l}\text { S12T021200 } \\
\text { S12R000516 }\end{array}$ & $09-27-2012$ & $10-01-2012$ & $\begin{array}{l}\text { Black particle } \\
\text { Floor scraping near Riser 83 }\end{array}$ \\
\hline 2AY-12-ANU3 & $\begin{array}{l}\text { S12T021354 } \\
\text { S12R000529 }\end{array}$ & $10-15-2012$ & $10-16-2012$ & $\begin{array}{l}\text { Air Slot - Bulk } \\
\text { near Riser 90 }\end{array}$ \\
\hline 2AY-12-ANU5 & $\begin{array}{l}\text { S12T021355 } \\
\text { S12R000531 }\end{array}$ & $10-15-2012$ & $10-16-2012$ & $\begin{array}{l}\text { Mound Sample - Bulk } \\
\text { near Riser 90 }\end{array}$ \\
\hline 2AY-12-ANU3A & $\begin{array}{l}\text { S12T021346 } \\
\text { S12R000533 }\end{array}$ & $10-17-2012$ & $10-18-2012$ & $\begin{array}{l}\text { Air Slot - Bulk A } \\
\text { near Riser 90 }\end{array}$ \\
\hline 2AY-12-ANU5A & $\begin{array}{l}\text { S12T021356 } \\
\text { S12R000534 }\end{array}$ & $10-17-2012$ & $10-18-2012$ & $\begin{array}{l}\text { Mound Sample - Bulk A } \\
\text { near Riser 90 }\end{array}$ \\
\hline
\end{tabular}

The initial samples consisted of particulate adhered to duct tape which had been placed in clear yellow plastic bags. These samples were received at the lab on August 10, 2012. One additional tape sample (AY-102 Annulus-1-2 S12R000486) was partially digested for radiochemical

\footnotetext{
${ }^{1}$ ASPEX is a registered trademark of ASPEX Instruments, Delmont, Pennsylvania.

${ }^{2}$ Rigaku is a registered trademark of Rigaku Corporation, Tokyo, Japan.

${ }^{3}$ Nikon is a registered trademark of Nikon, Inc., Melville, New York.
} 
analysis (RPP-RPT-53511, Final Report for Tank 241-AY-102 Annulus Solid Sample Taken in August, 2012) and not examined for solid phase characterization.

Additional samples were obtained from the annulus in the vicinity of Risers 83 and 90 using different sampling methods (RPP-PLAN-53352, Tank 241-AY-102 Annulus Sampling and Analysis Plan). These samples were transported to the laboratory for chemical analysis and solid phase characterization. The observations made during sample breakdown and the analytical results are presented in RPP-RPT-54071, Final Report for Tank 241-AY-102 Annulus. The sample amounts received at the lab are recorded on Table 1 of RPP-RPT-54071.

A sample of scrapings from the annulus floor near Riser 83 was received at 222-S on September 27, 2012. The material was split into two fractions in the 11A hot cells. The white salt-like crystalline portion of the sample was identified as Sample S12T021101 (renumbered S12R000514 for SPC). A large dark chunk which showed an attraction to a magnet was separated and identified as Sample S12T021200 (S12R000516).

Two more samples were received at 222-S on October 15, 2012. Samples 2AY-12-ANU3 (S12T021354/S12R000529) and 2AY-12-ANU5 (S12T021355/S12R000531) (Figure 22) had very limited sample material, and the bulk of the material was composed of iron oxide/hydroxide.

The final two samples described in this report were received at the 222-S Laboratory on October 17, 2012. The samples, identified as 2AY-12-ANU3A (S12T021346/S12R000533) and 2AY-12-ANU5A (S12T021356/S12R000534), were examined in the 11A hot cells, photographed, weighed, transferred to glass jars, and transferred to the contamination area portion of the lab.

\subsection{SOLID PHASE CHARACTERIZATION ANALYSIS OF TANK 241-AY-102 ANNULUS-1 TAPE SAMPLES S12R000485, S12R000487, AND S12R000488}

The first sample, received at 222-S in August 2012, consisted of adhesive duct tape that had portions of yellow plastic bags adhering to it. The tape and plastic bag were cut into four sections in the 11A hot cells. These sections were examined, and individual particles were removed from three of the four pieces of tape (Figure 1). Tape \#2 (S12R000486) had already been subsampled for radiochemistry and was not further sampled for SPC. 
Figure 1. Tank 241-AY-102 Annulus-1-1, -2, -3, and -4.

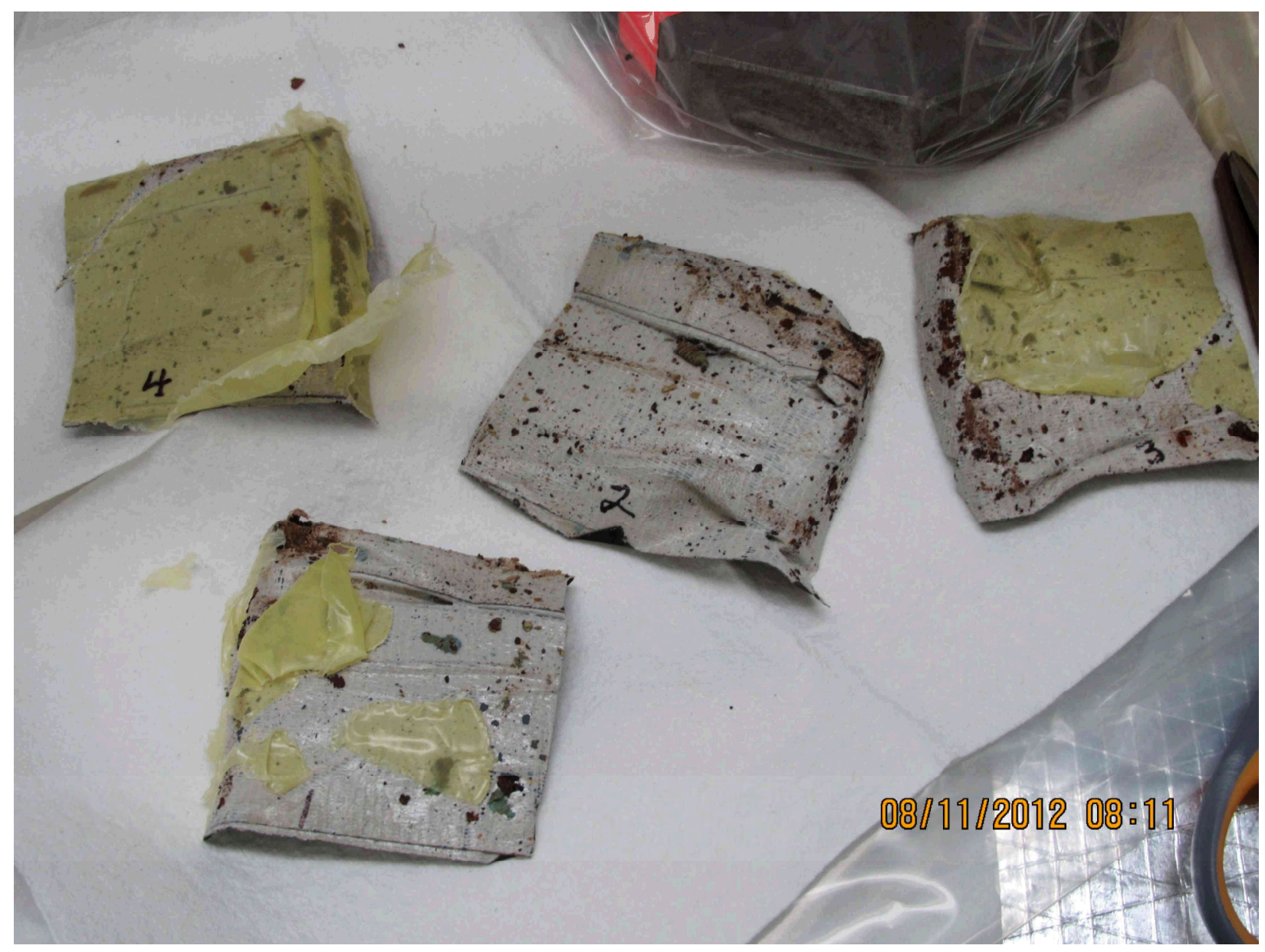

Analysis by SEM was conducted using standard procedure ATS-LT-161-100, "222-S Laboratory Sample Preparation and Operating Procedure for Scanning Electron Microscopes." The removed particulate was placed on adhesive tabs on SEM specimen mounts without regard for which tape segment they came from. The selected particulate was examined first on a binocular microscope, then carbon-coated and examined on the SEM. The SEM images are paired with EDS spectra, with the SEM image to the left. The area or spot examined by the EDS detector is marked on the image by a yellow cross or a box. The corresponding EDS spectrum is to the right. Both secondary electron images (SEI) and backscattered electron images (BEI) were collected for evaluation.

The particulate appears to be dominated by rust (Figure 2). Only a few examples of the rust were examined and found to be composed primarily of iron and oxygen, as expected. 
Figure 2. Secondary Electron Image and Energy Dispersive X-ray Spectrometer Spectrum from Tape Samples.
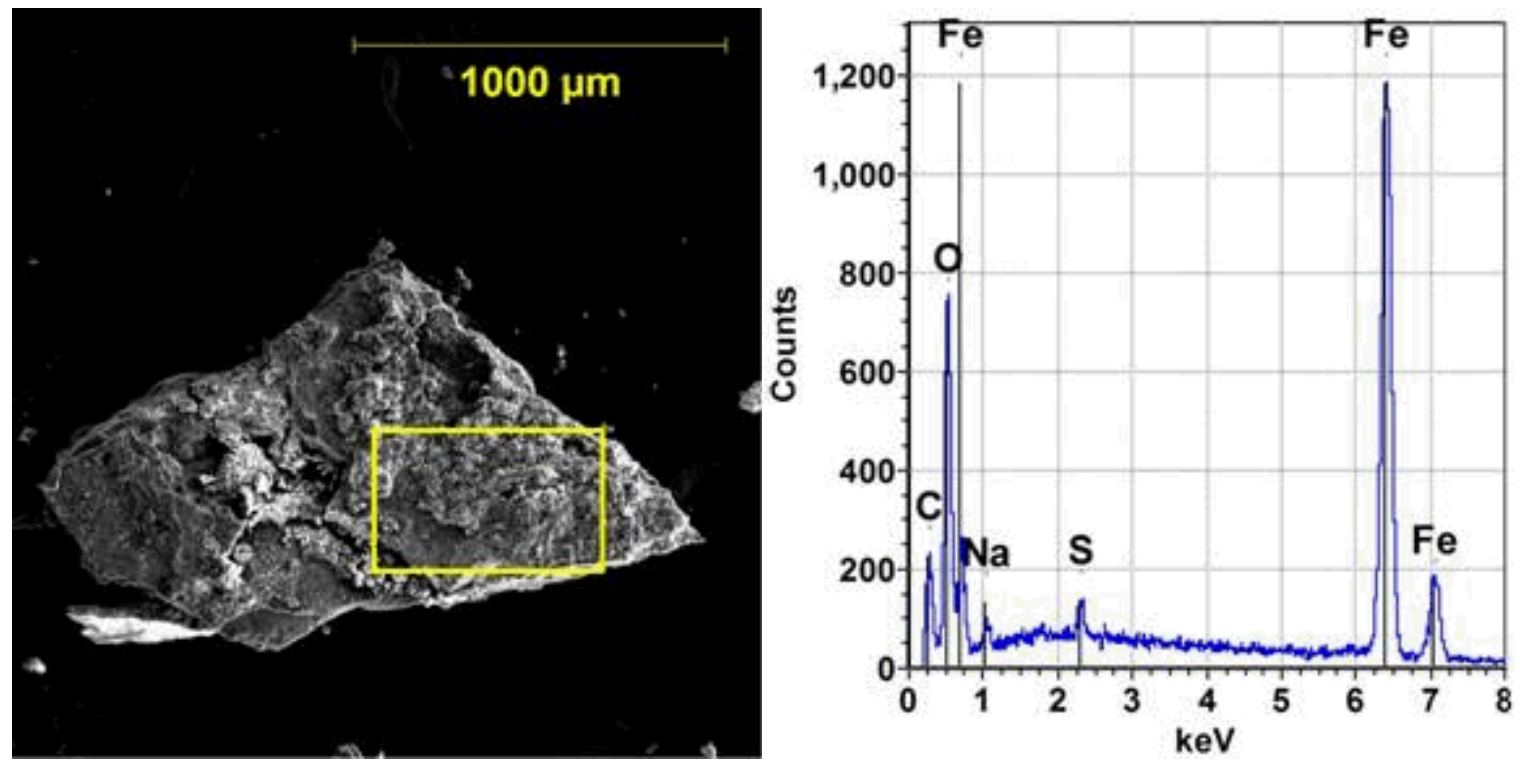

The scattered blue particulate appears to be flakes of paint. The EDS signature indicates that a kaolinite mineral is the filler in the paint and that there are cellulose fibers present throughout as well as rust adhering to one side. (Figure 3).

Figure 3. Optical (left), Backscatter Electron (right) Images of Paint Flake, Energy Dispersive X-ray Spectrometer Spectrum from Area in Yellow Box.
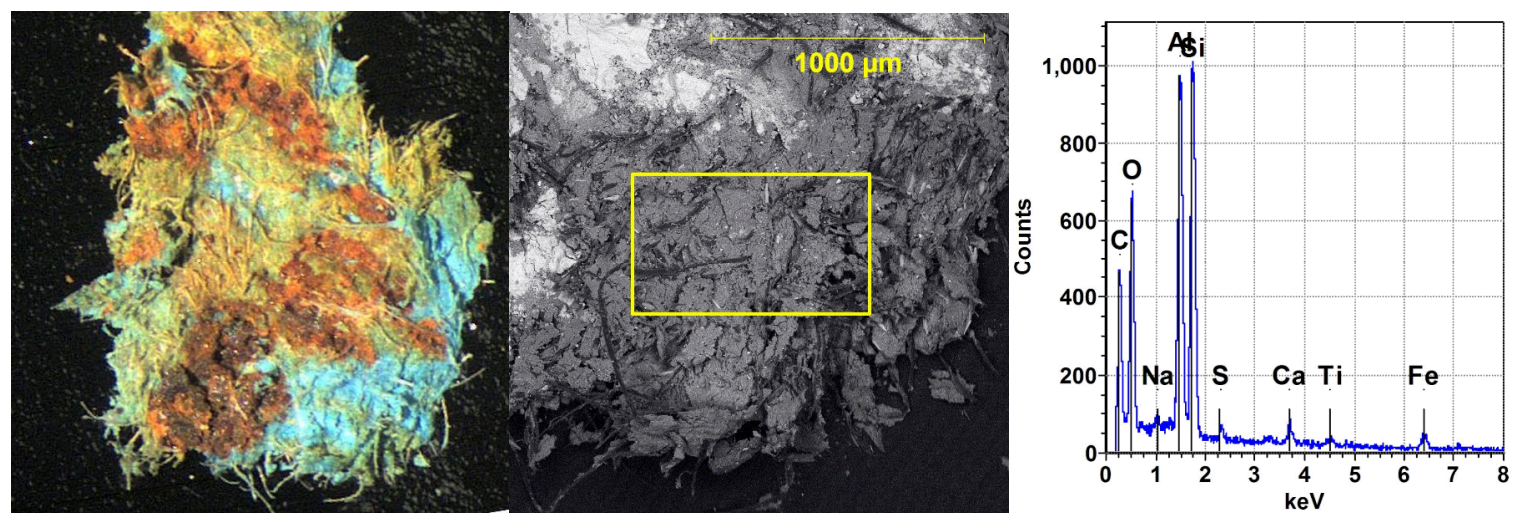

The remainder of the particulate is primarily light gray to amber-colored aggregates of finegrained crystalline material. Several of these particles were examined. The chemistry was fairly uniform, with sodium, potassium, carbon, oxygen, nitrogen, phosphorous, and chlorine identified in the EDS spectra (Figure 4). 
Figure 4. Secondary Electron Image and Energy Dispersive X-ray Spectrometer Spectrum of Area Boxed in Yellow.
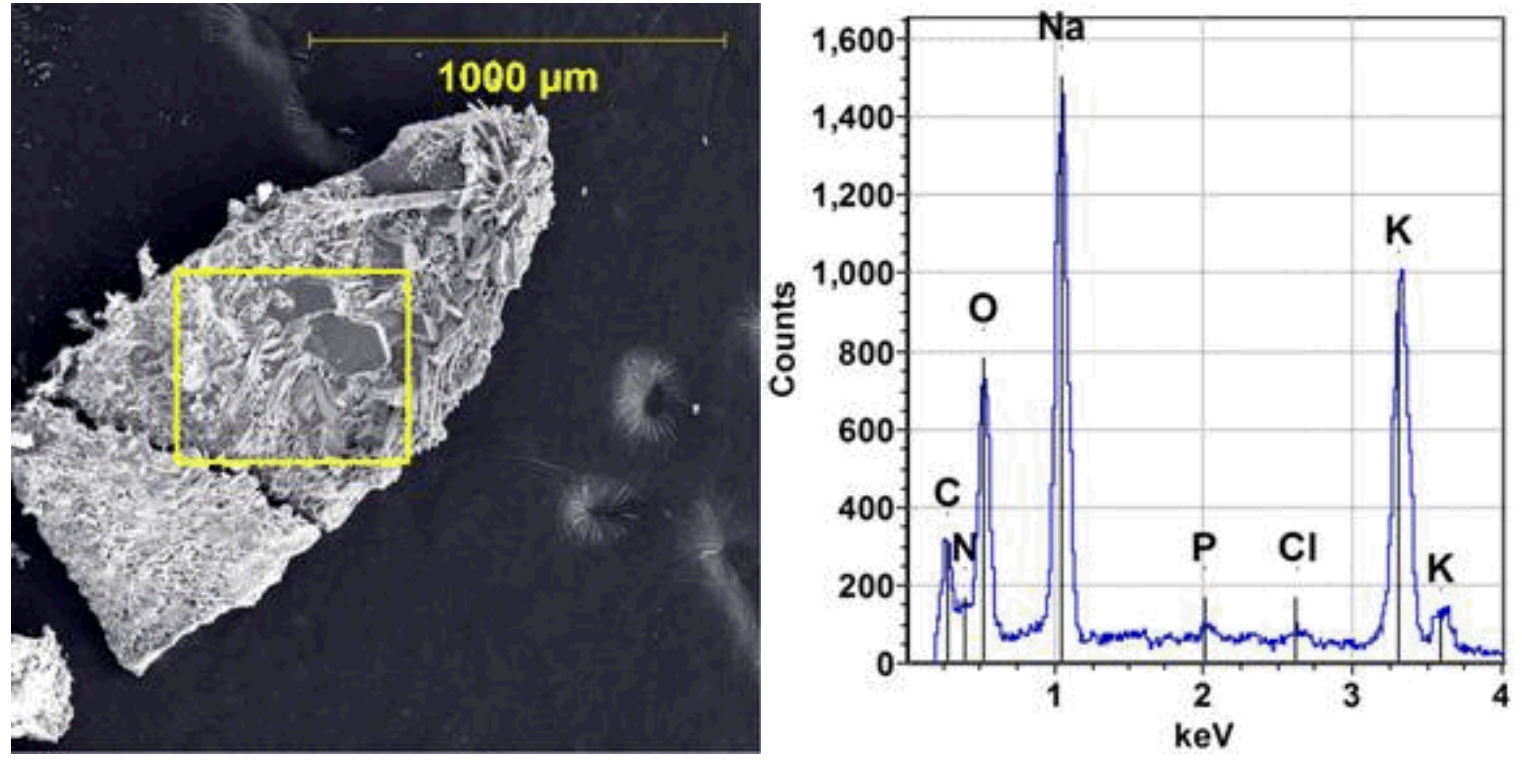

The largest crystals are blocky, equant crystals of sodium nitrate (nitratine, $\mathrm{NaNO}_{3}$ ). An example is shown in Figure 5.

Figure 5. Secondary Electron Image and Energy Dispersive X-ray Spectrometer Spectrum from Tape Samples.
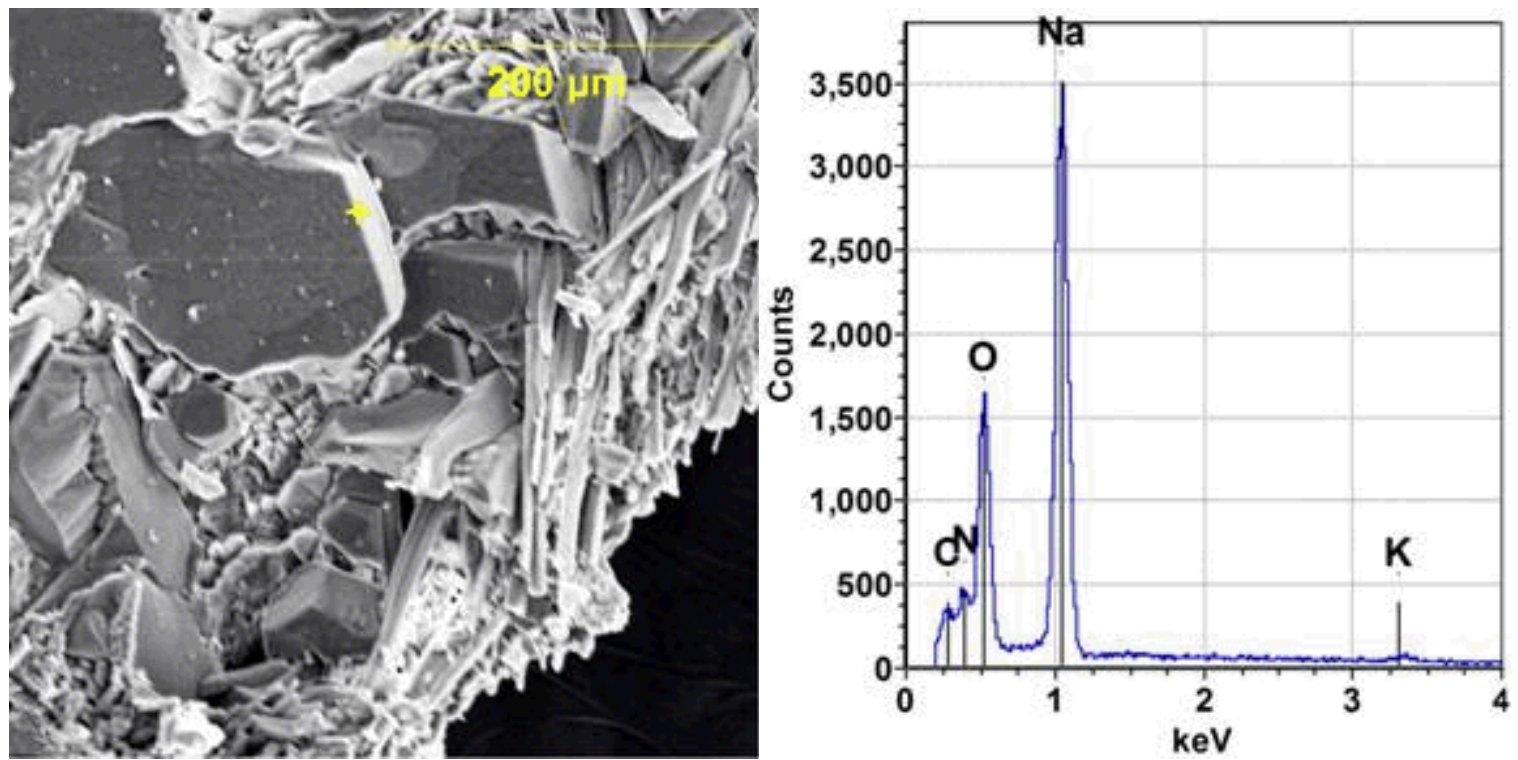
These are mixed with a blade-like or lath-like potassium-rich phase, shown in Figure 6.

Figure 6. Secondary Electron Image and Energy Dispersive X-ray Spectrometer Spectrum from Tape Samples.
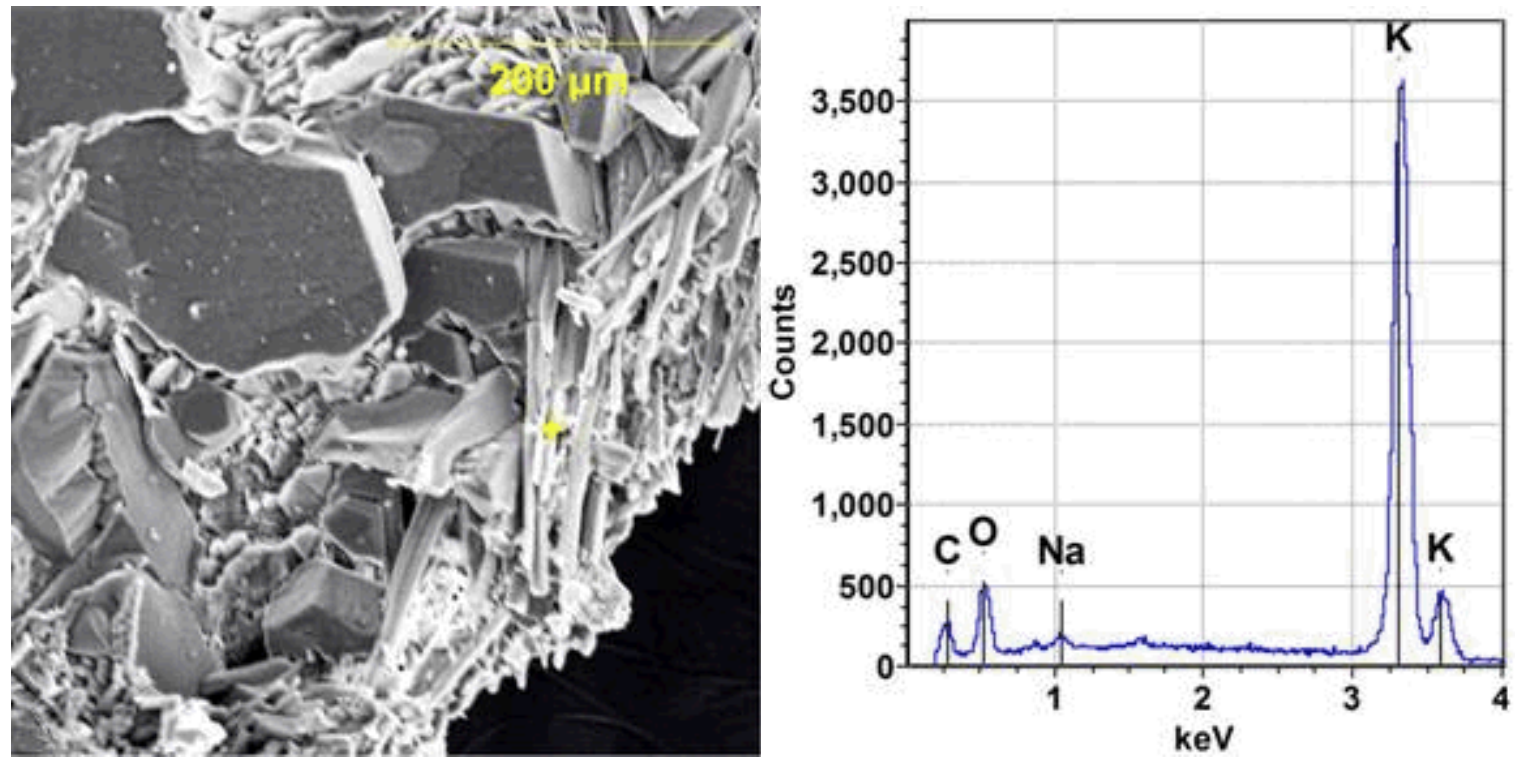

Potassium chloride was also found with these salt phases, shown in Figure 7.

Figure 7. Secondary Electron Image and Energy Dispersive X-ray Spectrometer Spectrum from Tape Samples.
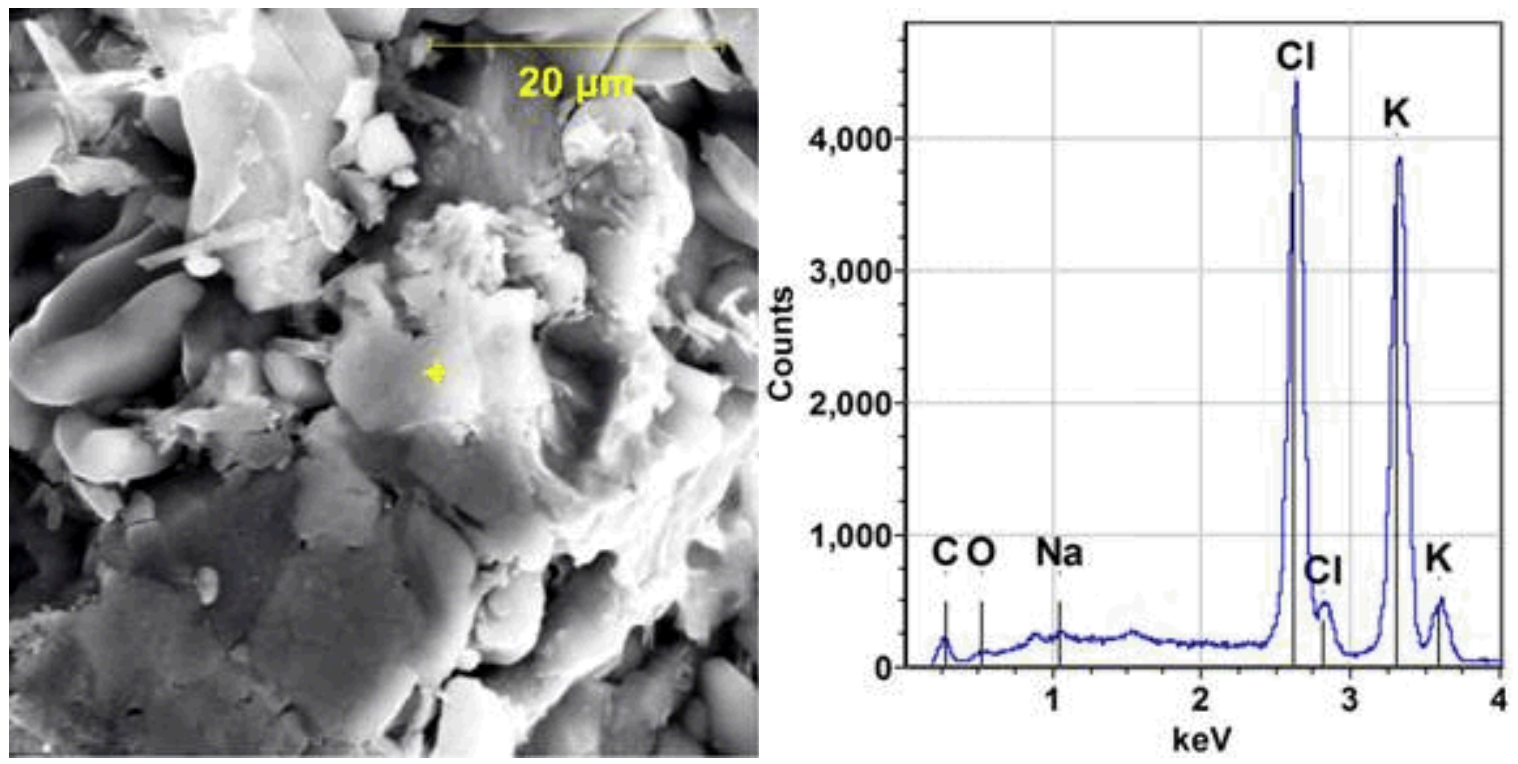
Sodium phosphate dodecahydrate $\left(\mathrm{Na}_{3} \mathrm{PO} 4 \cdot 12 \mathrm{H}_{2} \mathrm{O}\right)$ was also identified, based on the EDS chemistry and the particle morphology (Figure 8).

Figure 8. Secondary Electron Image and Energy Dispersive X-ray Spectrometer Spectrum from Tape Samples.
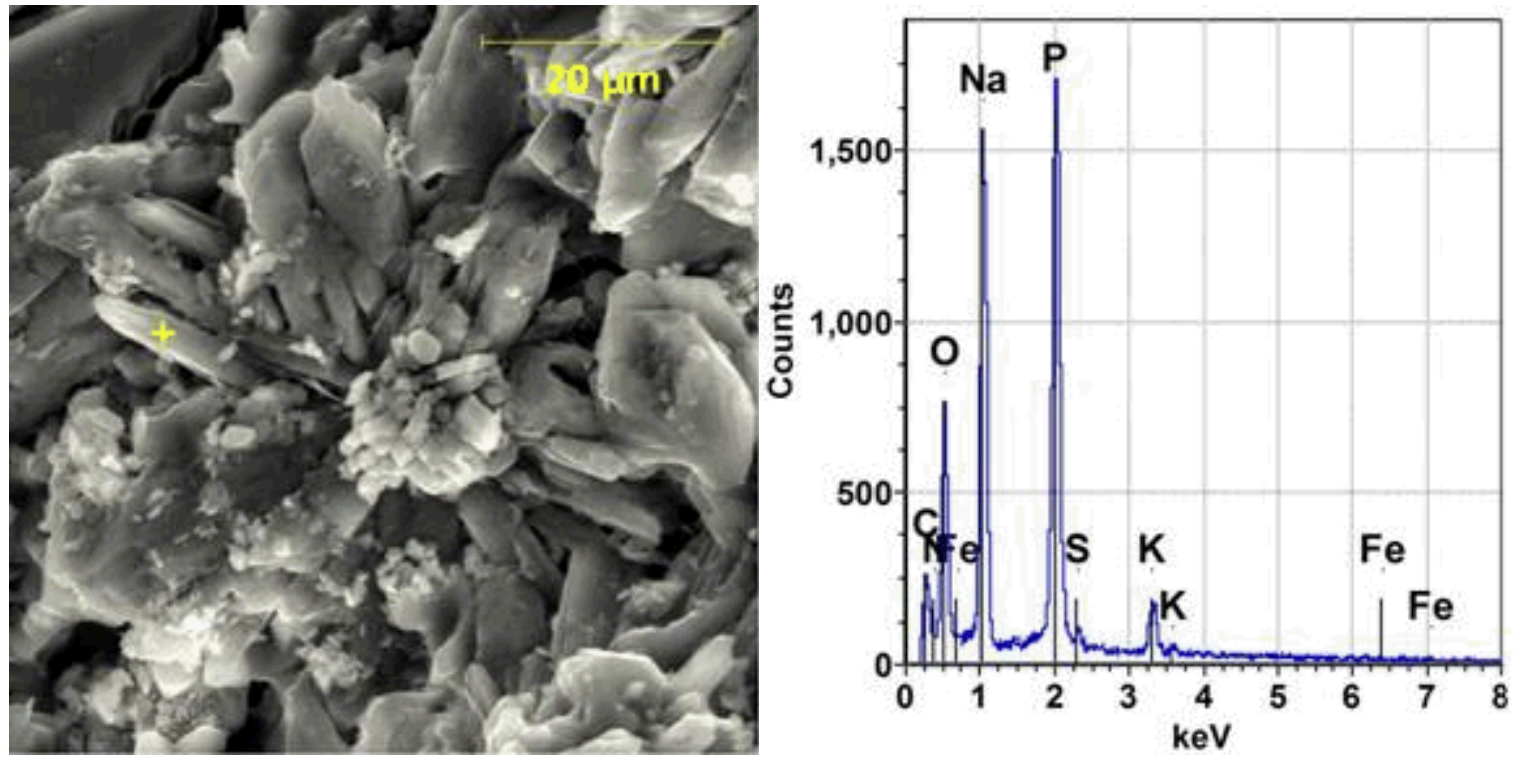

In addition, particulate consistent with sodium carbonate (thermonatrite, $\mathrm{Na}_{2} \mathrm{CO}_{3} \cdot \mathrm{H}_{2} \mathrm{O}$ ) was observed (Figure 9).

Figure 9. Secondary Electron Image and Energy Dispersive X-ray Spectrometer Spectrum from Tape Samples.
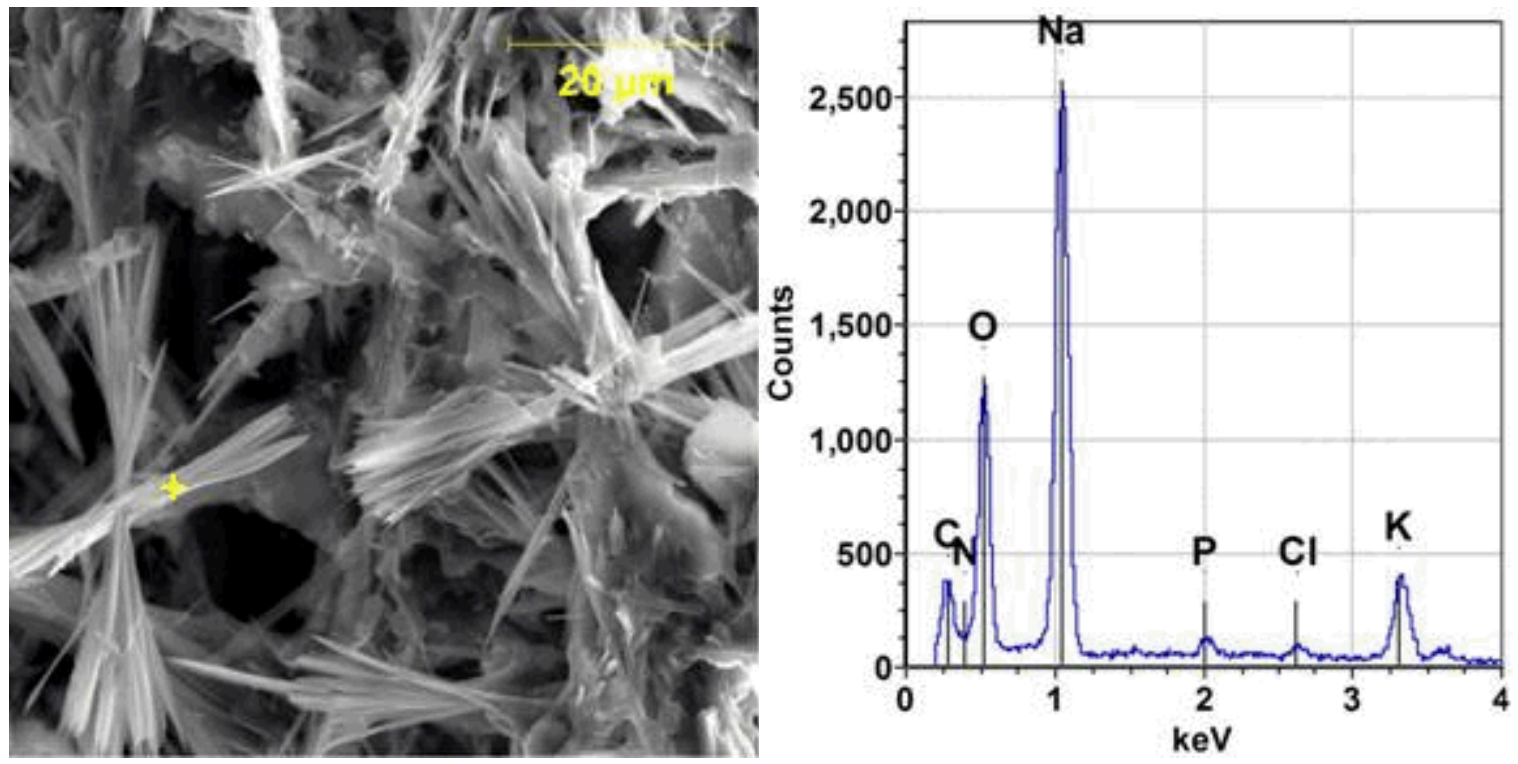
A trace amount of sodium fluoride phosphate hydrate (natrophosphate, $\mathrm{Na}_{7} \mathrm{~F}\left(\mathrm{PO}_{4}\right)_{2} \cdot 19 \mathrm{H}_{2} \mathrm{O}$ ) was also found (Figure 10).

Figure 10. Secondary Electron Image and Energy Dispersive X-ray Spectrometer Spectrum from Tape Samples.
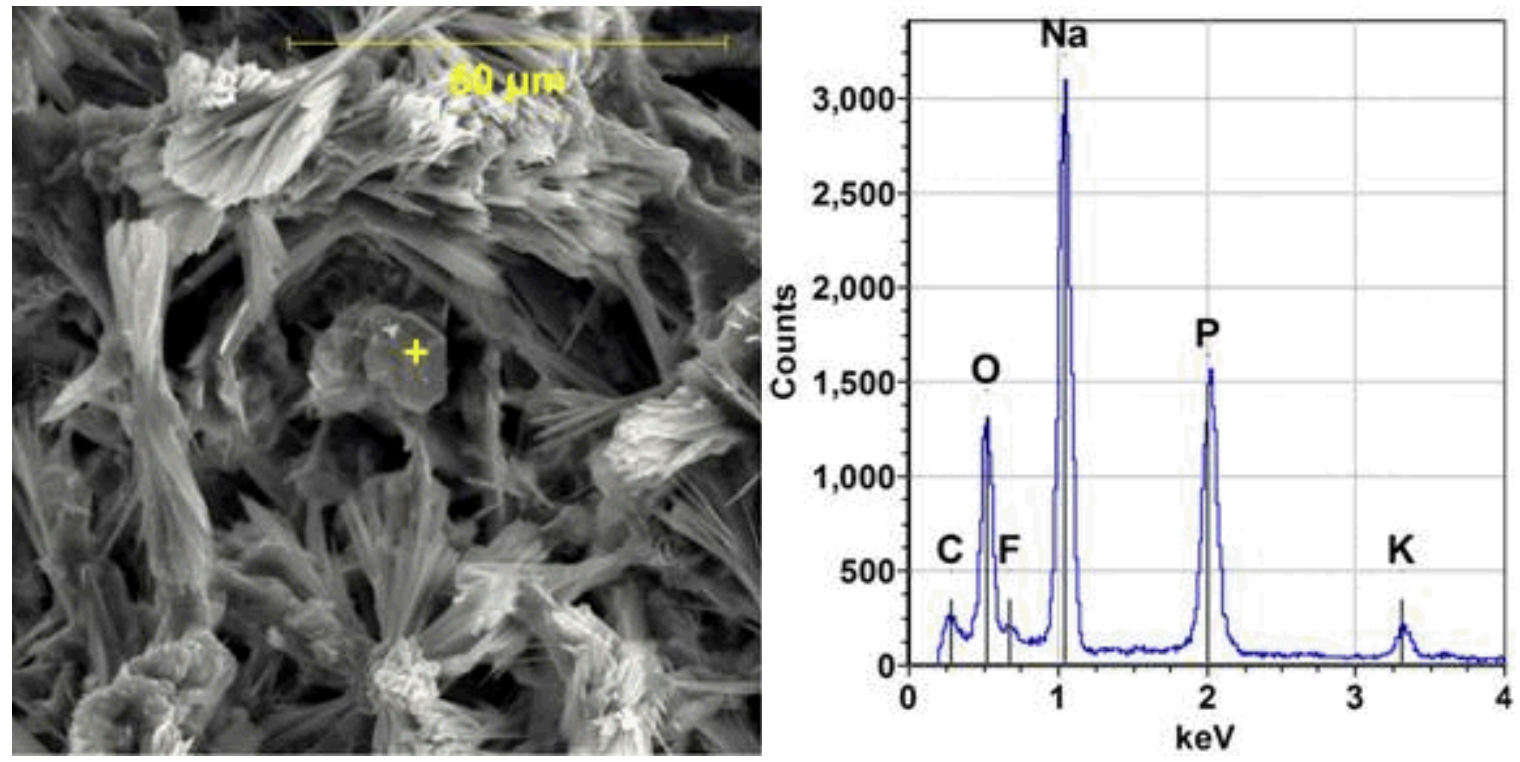

The sodium phases identified in these samples are all water soluble phases that have been identified in tank waste. Potassium is generally rare in tank waste. However, the supernatant that currently resides in tank AY-102 is high in potassium (RPP-RPT-44630, Derivation of BestBasis Inventory for Tank 241-AY-102 as of January 1, 2012). This indicates that the supernatant is the source for the potassium observed in some of the samples.

\subsection{SOLID PHASE CHARACTERIZATION ANALYSIS OF 2AY-12-ANU1 SAMPLES S12T021101 (S12R000514) WHITE AND S12T021200 (S12R000516) BLACK}

A sample of scrapings from the annulus floor near Riser 83 was received at 222-S on September 27, 2012 (Figure 11). This sample was collected using the Off Riser Sampler (RPP-PLAN-53352). The material was split into two fractions while in the 11A hot cells. The white salt-like crystalline portion of the sample was identified as Sample S12T021101 (renumbered S12R000514 for SPC). A large dark chunk which showed an attraction to a magnet was separated and identified as Sample S12T021200 (S12R000516). 
Figure 11. Hot Cell Photo of 2AY-12-ANU1 Samples.

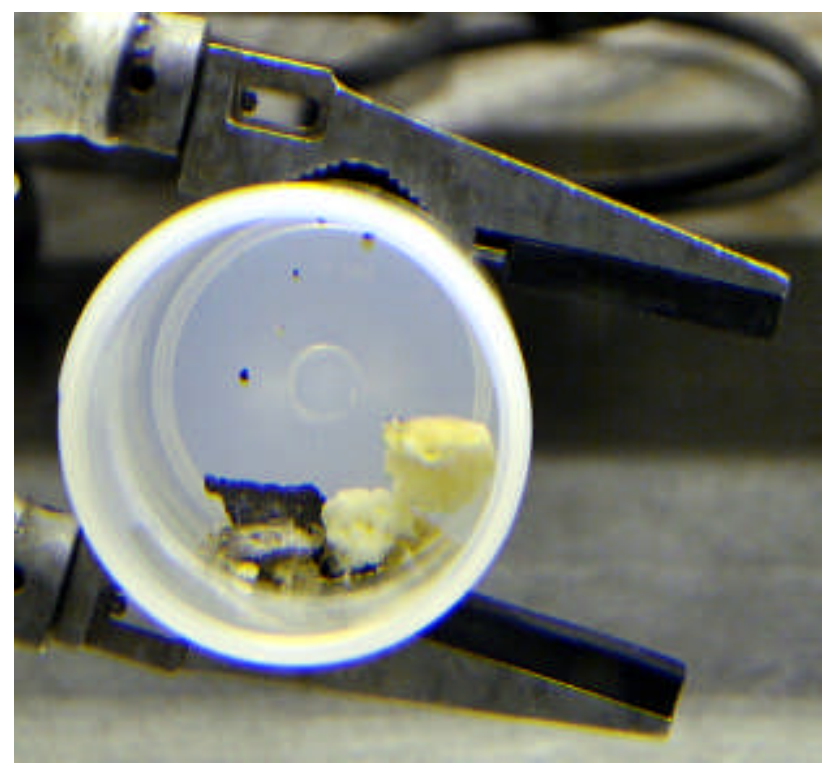

Both subsamples were crushed in a mortar and pestle in the hot cells. During crushing, the white chunks became noticeably moister, either through release of pore water or bound water, or through deliquescence.

Samples were prepared for XRD, SEM, and PLM analysis using standard procedures ATS-LT-507-101, “222-S Laboratory X-Ray Diffractometry (XRD),"ATS- LT-161-100, and ATS-LT-519-107, "222-S Laboratory Polarized Light Microscopy,” respectively. Water was not used in the sample preparation steps in order to avoid altering water-soluble compounds. The SEM images shown below are secondary electron images (SEI) paired with an EDS of the area marked with the + in the photo, unless otherwise noted.

For XRD analysis, a portion of each sample was individually ground, placed in the well of a quartz zero-background slide, compressed with the plane of a glass slide, and fixed with collodion binder. The diffraction pattern (Figure 12) shows a series of peaks that are caused by the presence of crystalline solids in the sample. Below the diffraction pattern in Figure 12 are three sets of lines that show the relative position and intensity of the peaks that are found in the crystalline phases that were identified. The major phases of the white sample were identified by XRD analysis as thermonatrite $\left(\mathrm{Na}_{2} \mathrm{CO}_{3} \cdot \mathrm{H}_{2} \mathrm{O}\right)$ and nitratine $\left(\mathrm{NaNO}_{3}\right)$. Sodium nitrite $\left(\mathrm{NaNO}_{2}\right)$ was identified as a minor phase. At least one minor/trace phase remains unidentified in the diffraction pattern. The XRD spectrum was specifically reviewed for potassium salts, including potassium carbonate $\left(\mathrm{K}_{2} \mathrm{CO}_{3}\right)$, potassium carbonate dihydrate $\left(\mathrm{K}_{2} \mathrm{CO}_{3} \cdot 2 \mathrm{H}_{2} \mathrm{O}\right)$, potassium nitrite $\left(\mathrm{KNO}_{2}\right)$, potassium nitrate $\left(\mathrm{KNO}_{3}\right)$, and kalicinite $\left(\mathrm{KHCO}_{3}\right)$. None of these phases could be identified as present in the white sample (S12R000514). 
Figure 12. X-ray Diffraction Pattern for Sample S12R000514.

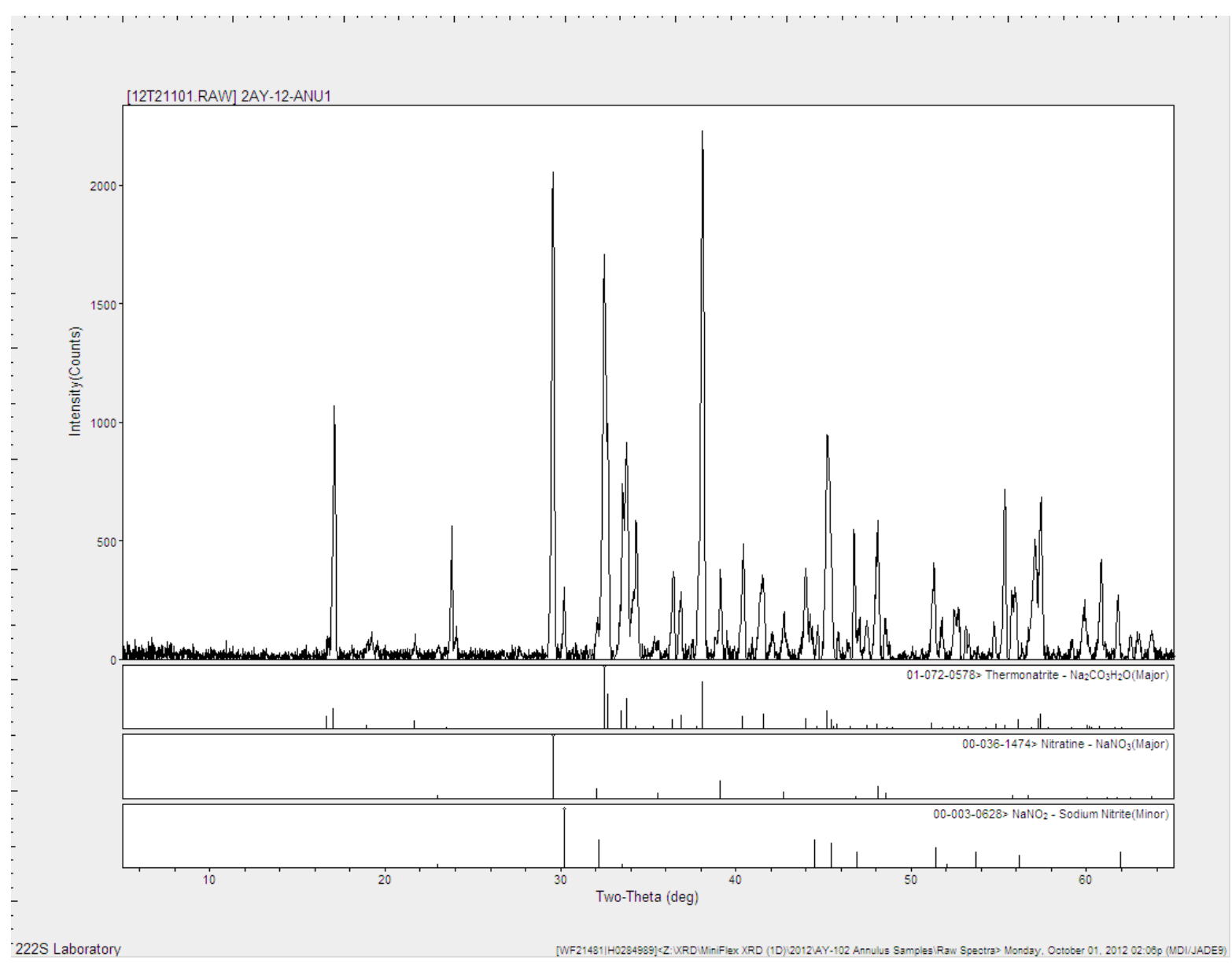


The SEM analysis confirms the presence of the thermonatrite and the nitrate/nitrite phases. Thermonatrite was the dominant phase (Figure 13).

Figure 13. Scanning Electron Microscopy Image and Energy Dispersive X-ray Spectrometry Spectrum of Sample S12R000514 (2AY-12-ANU1 White).
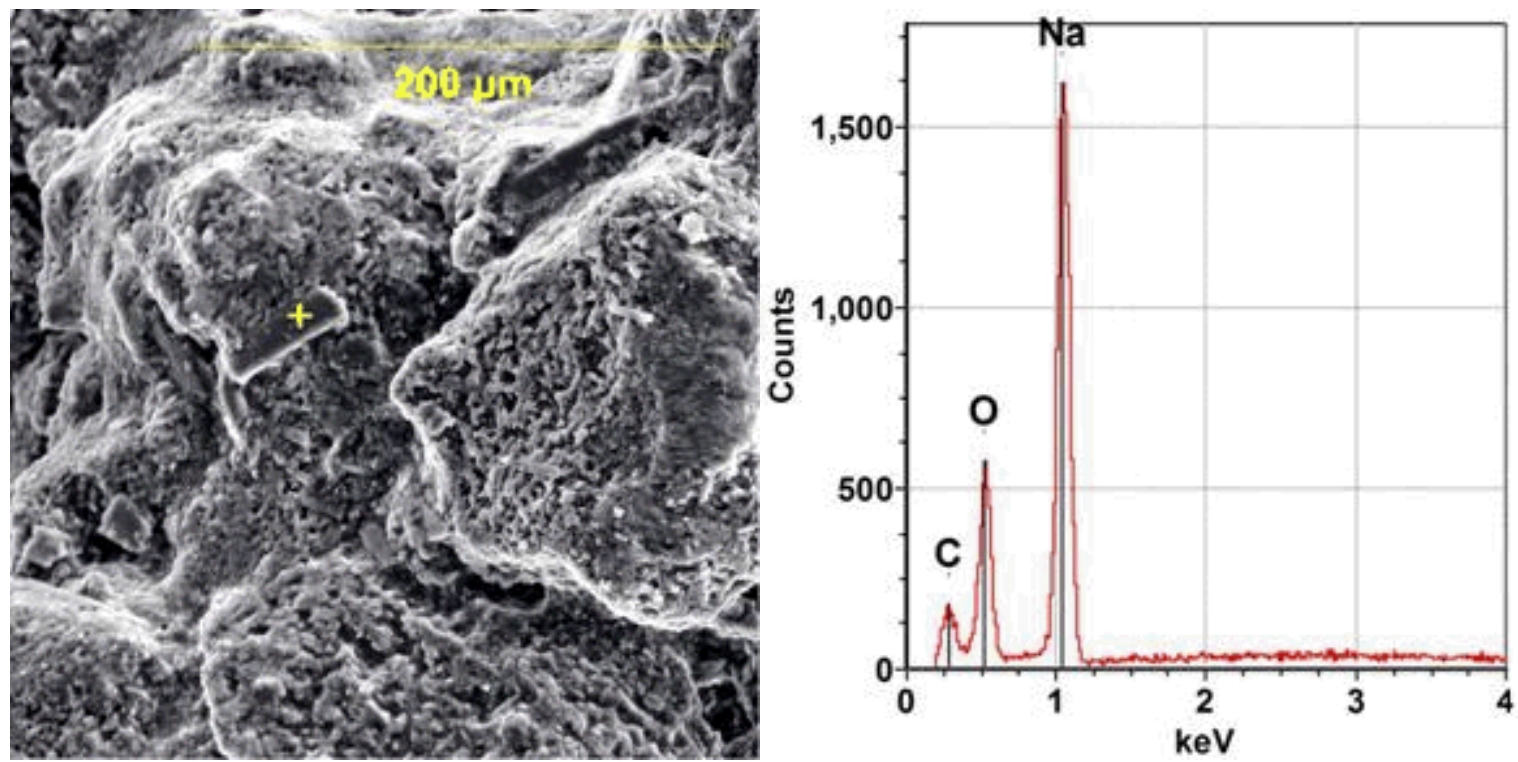

It is difficult for the SEM to distinguish the sodium nitrate from the nitrite, although one or both of these phases are certainly present (Figure 14).

Figure 14. Scanning Electron Microscopy Image and Energy Dispersive X-ray Spectrometry Spectrum of Sample S12R000514 (2AY-12-ANU1 White).
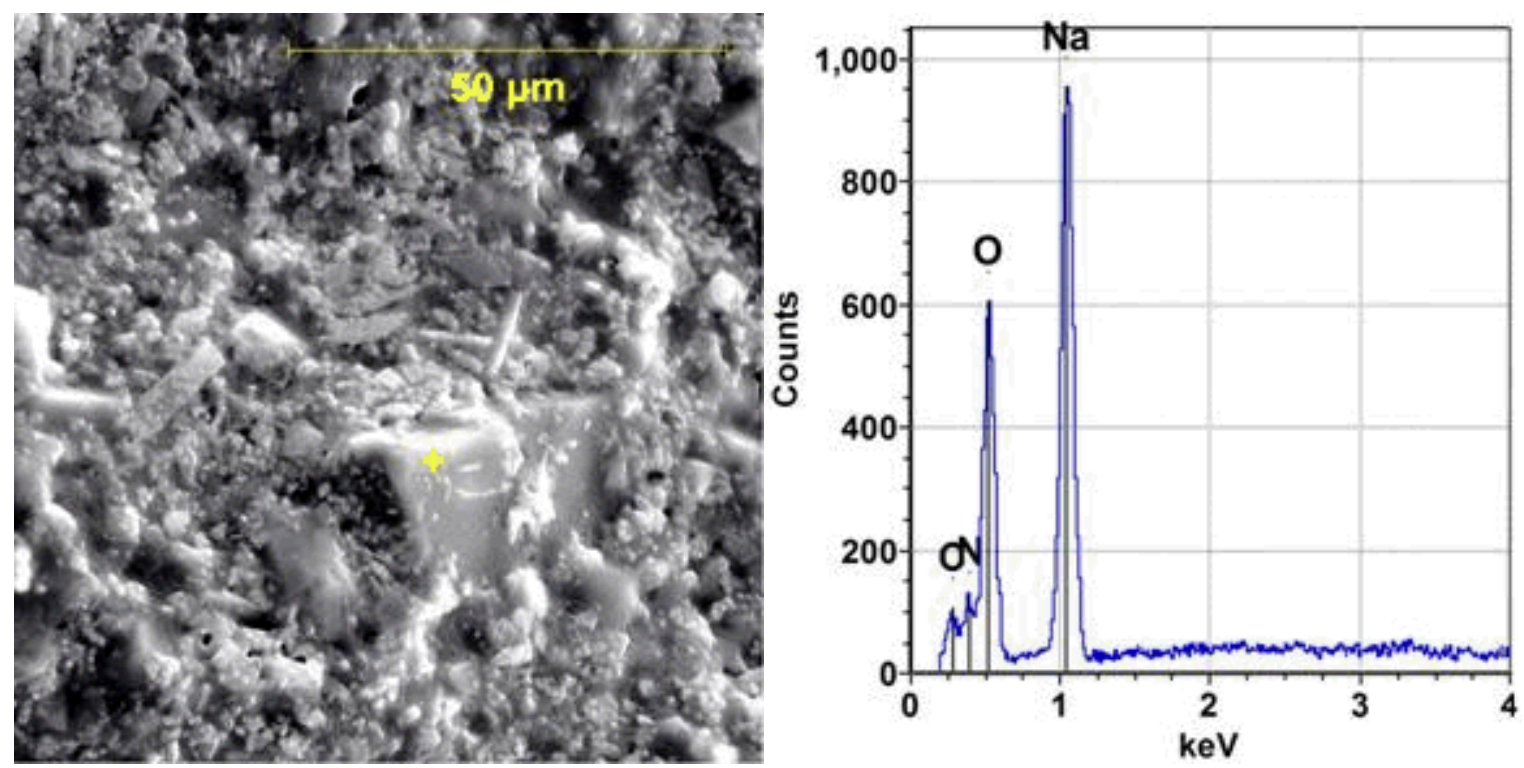
The SEM analysis indicates that the remaining material in the white particulate is a potassium salt (Figure 15).

Figure 15. Scanning Electron Microscopy Image and Energy Dispersive X-ray Spectrometry Spectrum of Sample S12R000514 (2AY-12-ANU1 White).
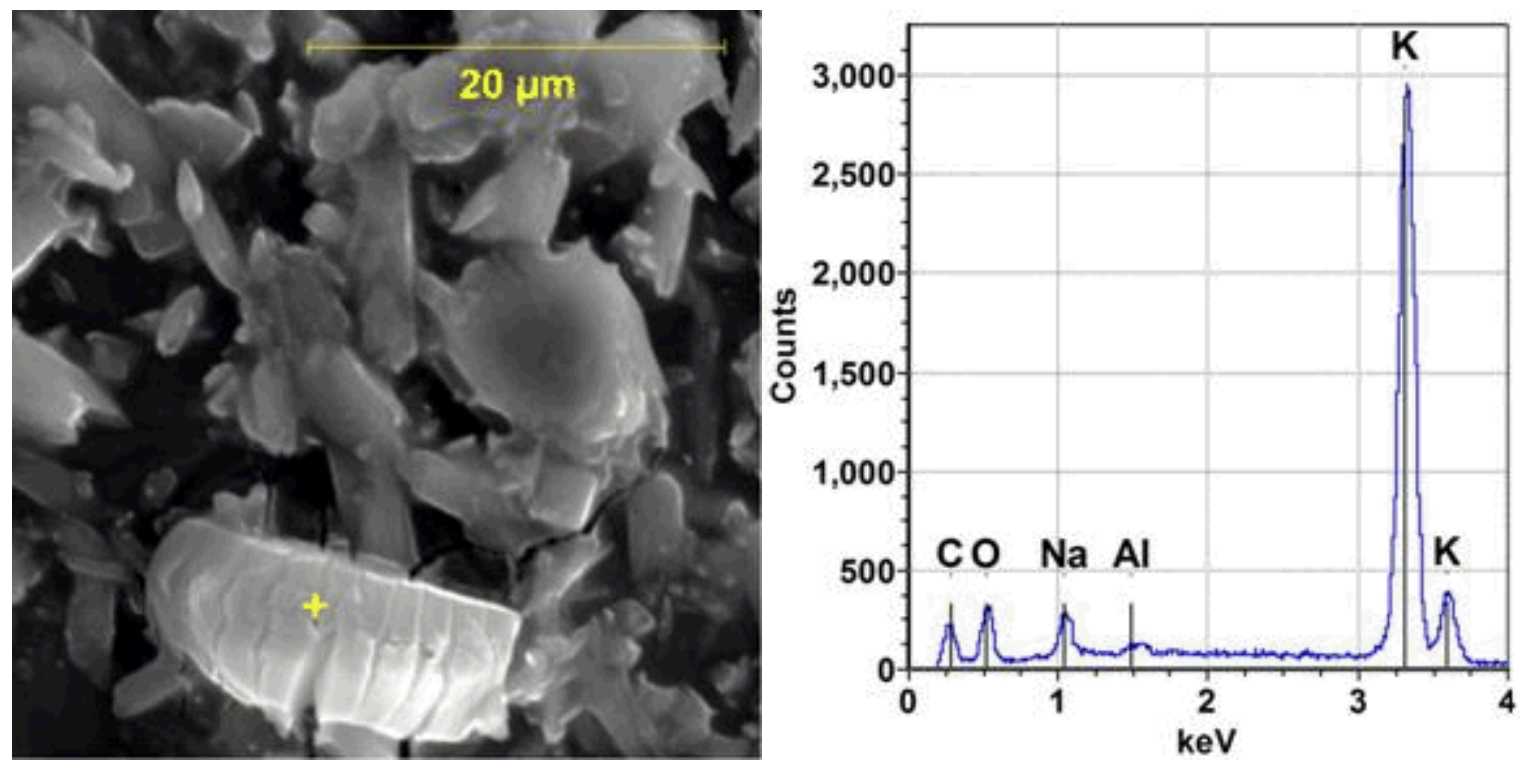

This phase is probably a hydrated potassium carbonate. It could not be identified in the XRD pattern, although there are peaks in the pattern that could not be attributed to the sodium phases mentioned above.

The potassium-bearing phase can be made to stand out in the SEM backscatter electron image (BEI). It is distinctly brighter than the sodium-bearing phases. The potassium-bearing phase appears to comprise about $5-10 \%$ of the sample by volume (Figure 16). 


\section{Figure 16. Scanning Electron Microscopy Image and Energy Dispersive X-ray Spectrometry Spectrum of Sample S12R000514 (2AY-12-ANU1 White).}

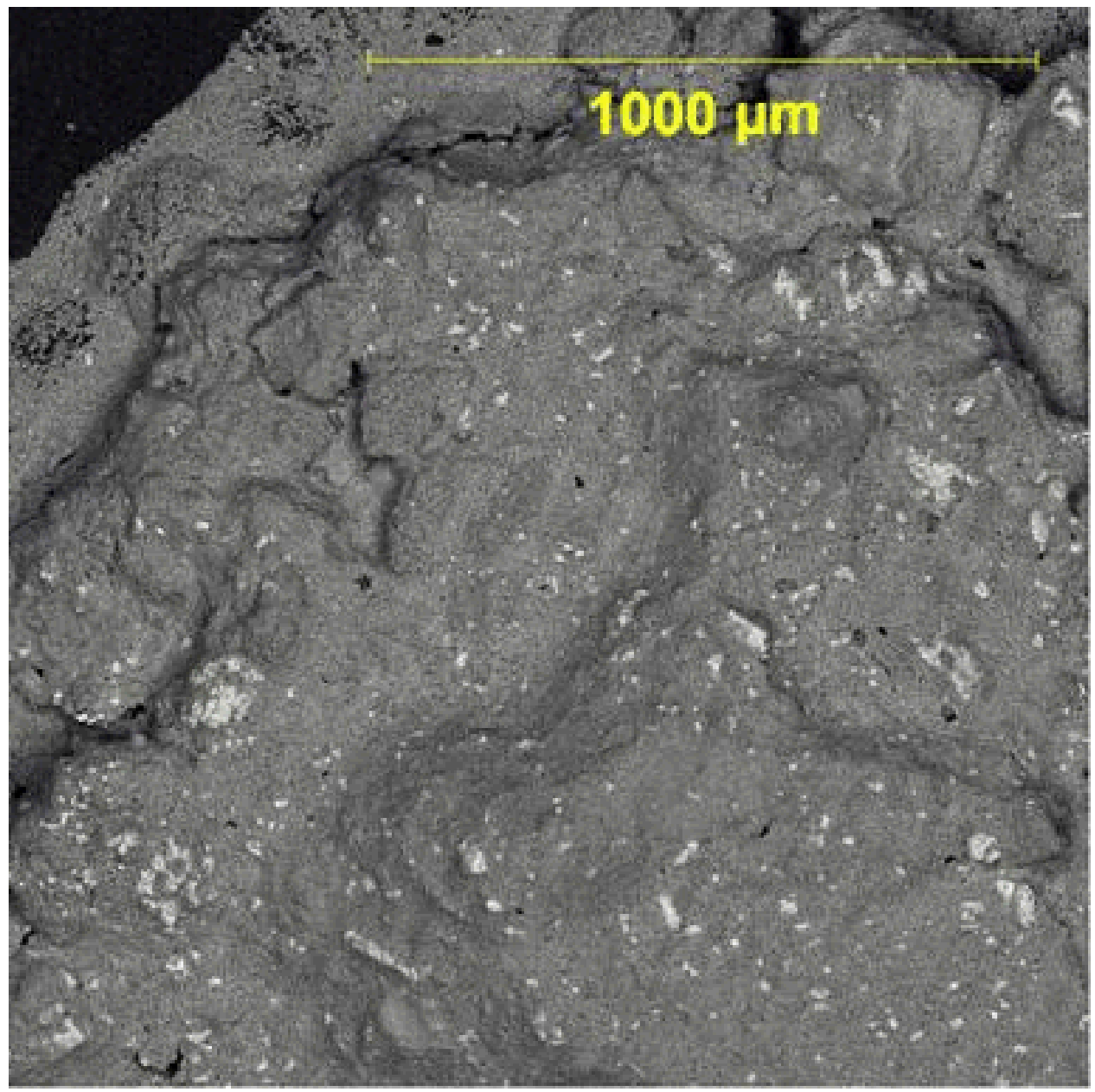

Trace amounts of a uranium-rich particulate were also observed in this sample. A single particle of potassium-rich particulate was observed that contained a significant amount of the element ruthenium. The sodium phosphate and potassium chloride particulate that were observed on the earlier sample were not observed in this current sample.

The white sample (S12R000514) was prepared for PLM analysis using 1.55 refractive index oil. The sample contained mostly broken crystals. Sodium nitrate, sodium carbonate, and sodium oxalate were identified. An unknown triangular phase with high birefringence (see close up on the right, Figure 17) was found on several occasions. 
Figure 17. Polarized Light Microscopy Images of Sample S12R000514 (2AY-12-ANU1 White), Crossed Polarizers and Red I Compensator Used.

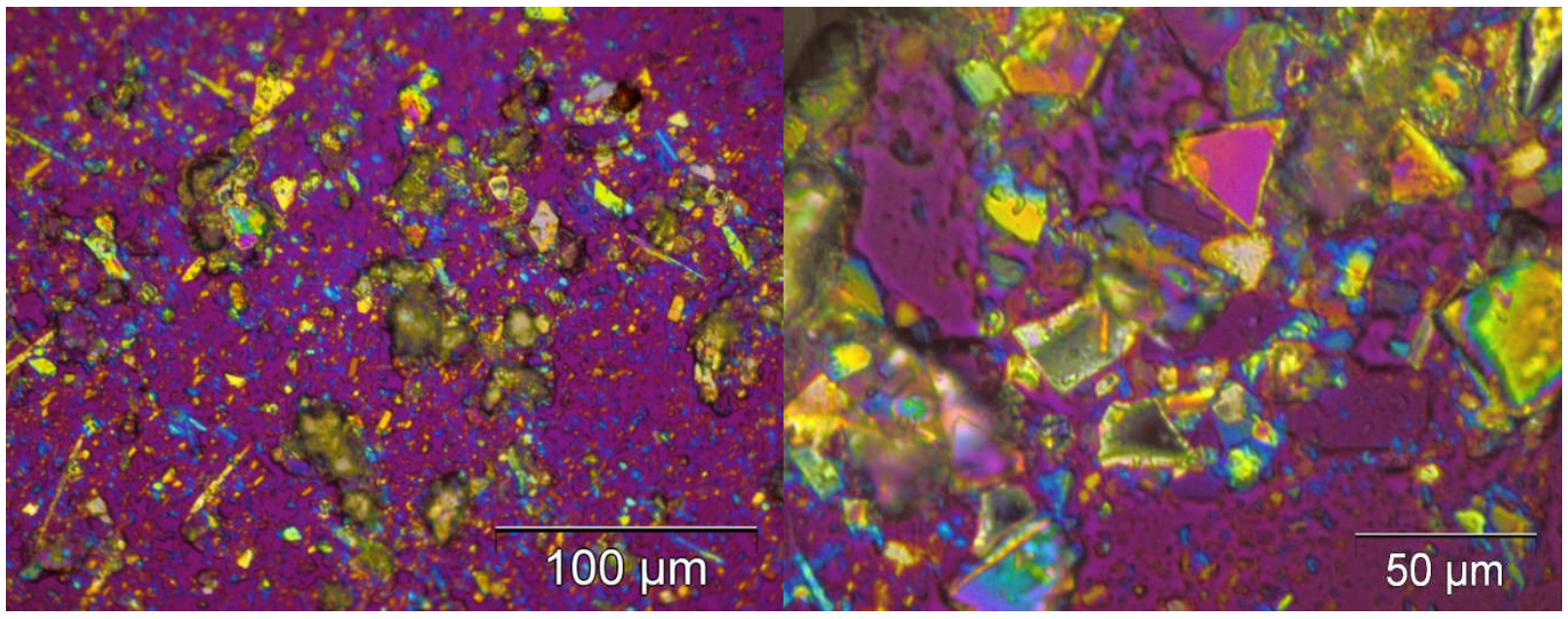

The XRD analysis of the dark material (S12R000516) revealed that the presumed iron-bearing, partially magnetic phase is not crystalline. The only crystalline peaks observed were of the same sodium-bearing phases found in S12R000514. However, the intensity (and therefore concentration) of these sodium phases is about a tenth as large as in Sample S12R000514.

Analysis by SEM confirmed that the sodium and potassium salts were present in this sample as well. However, the bulk of the sample is an iron oxide (Figure 18).

Figure 18. Scanning Electron Microscopy Image and Energy Dispersive X-ray Spectrometry Spectrum of Sample S12R000516 (2AY-12-ANU1 Black).
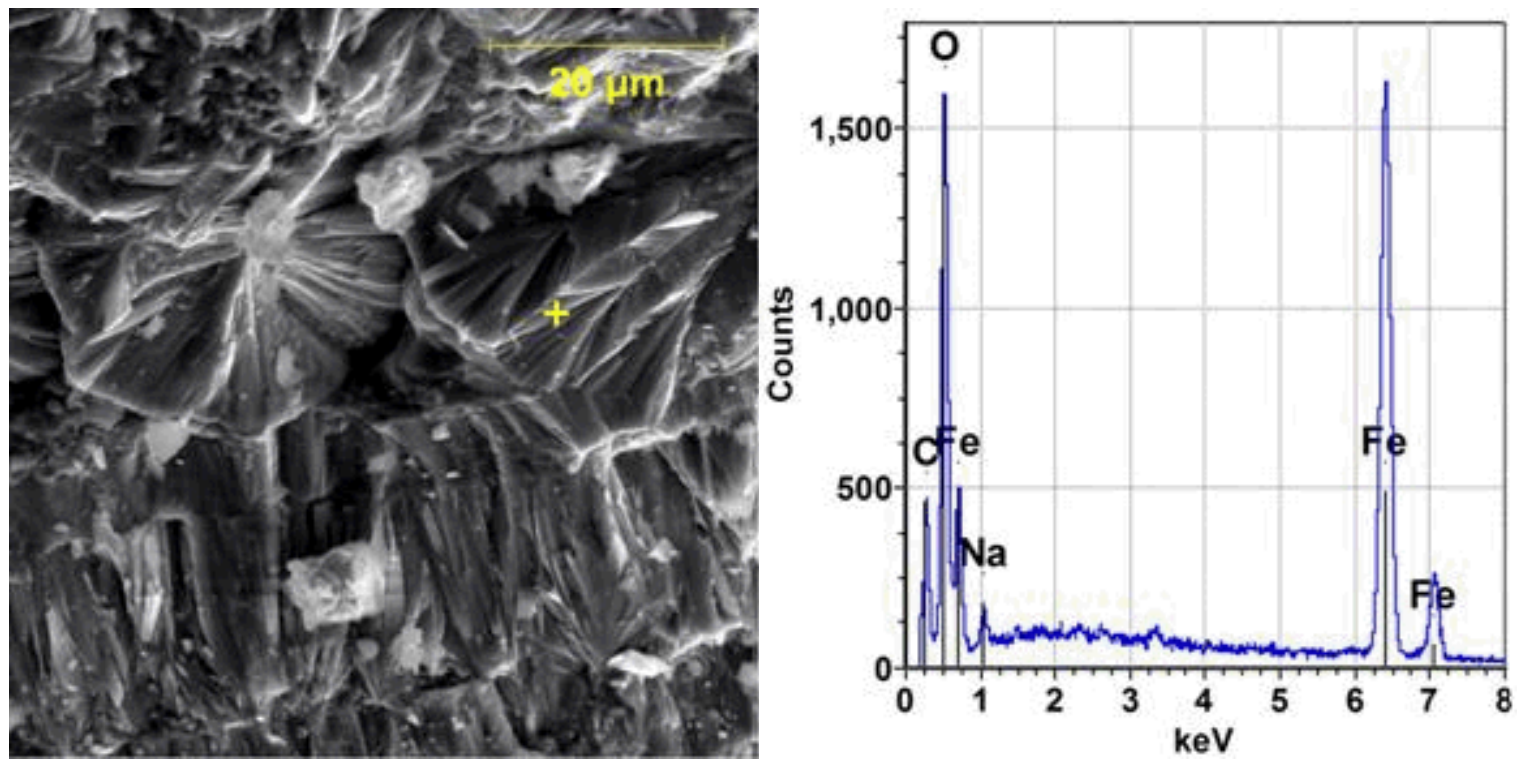
The iron-rich particulate in this sample appears layered, parallel to the long axis of the larger particles, as shown in BEI imaging (Figure 19).

Figure 19. Backscatter Electron Image of Sample S12R000516 (2AY-12-ANU1 Black).

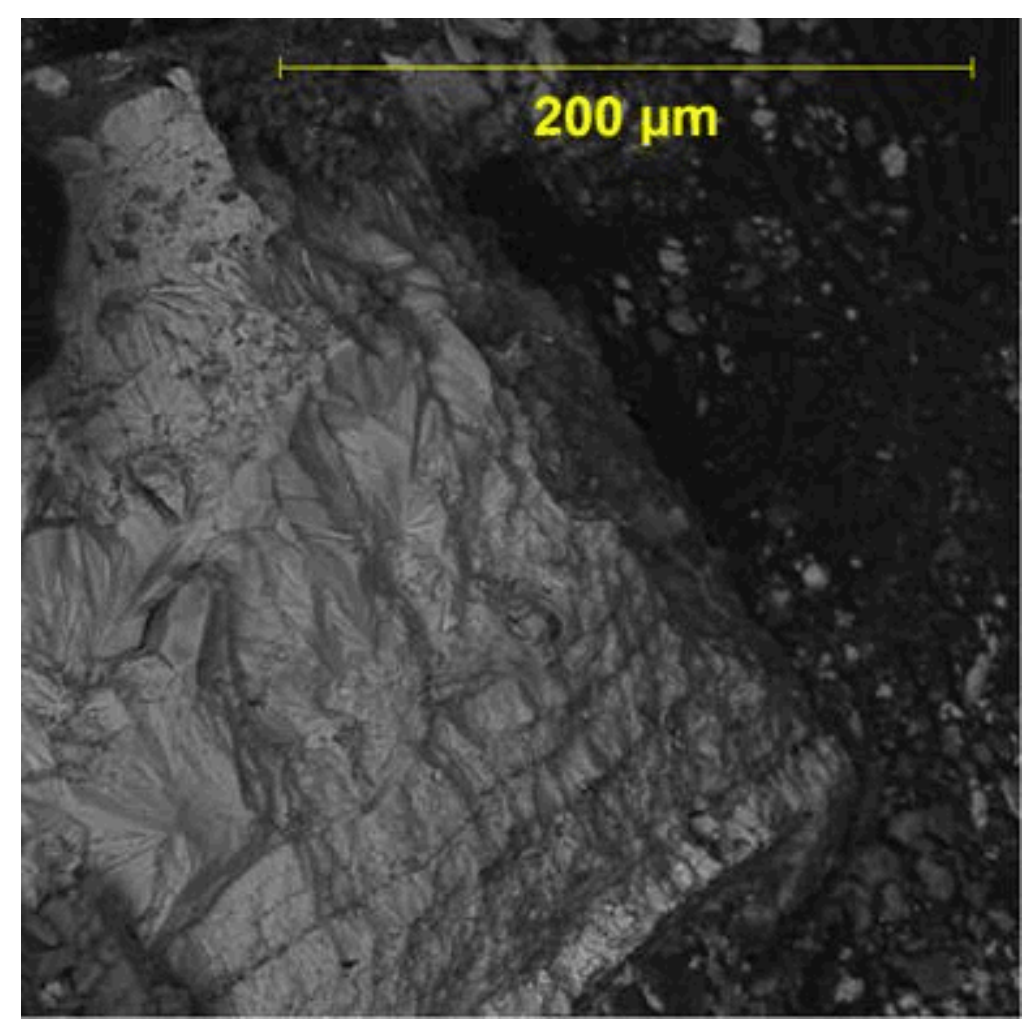

The black sample (S12R000516) was prepared for PLM analysis using the 1.55 refractive index oil. The sample contained predominantly tan and black opaque fine-grained material. Trace amounts of sodium nitrate, sodium carbonate, and sodium oxalate were observed (Figure 20). 
Figure 20. Polarized Light Microscopy Images of Sample S12R000516 (2AY-12-ANU1 Black), Crossed Polarizers and Red I Compensator Used.

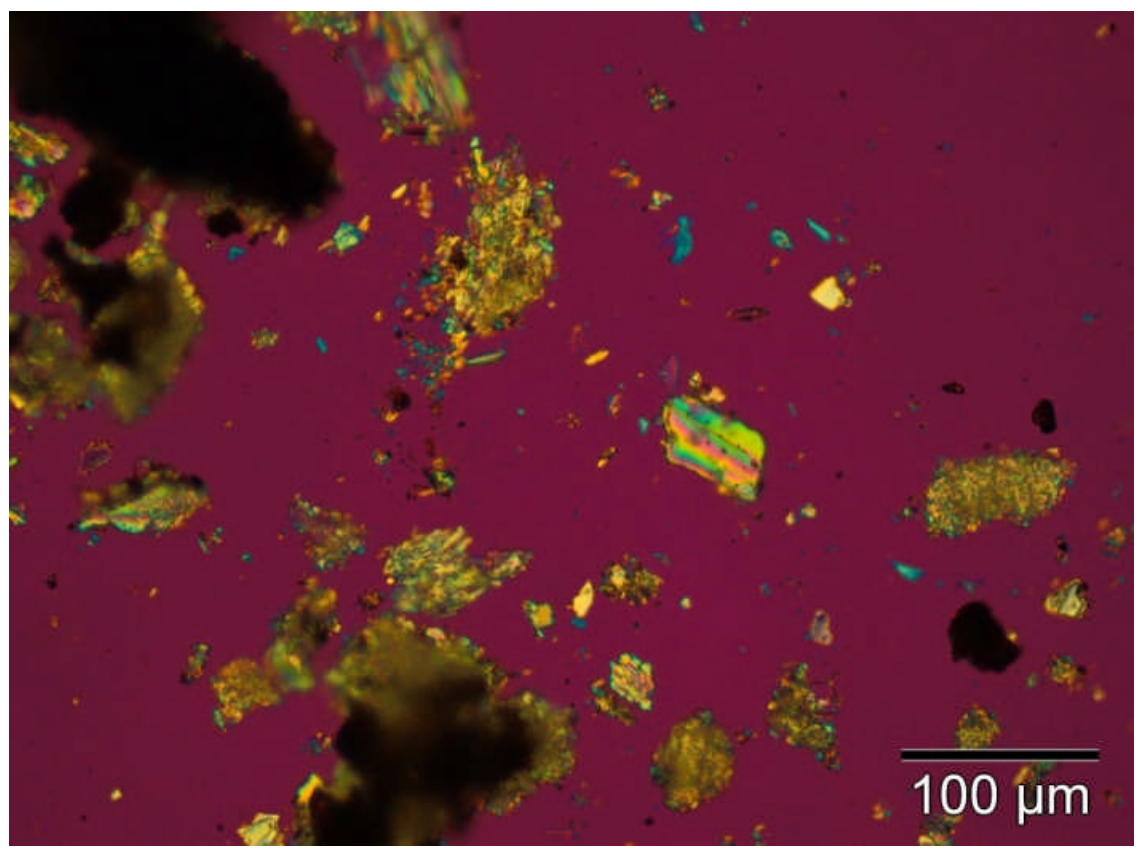

The chemistry, magnetic attraction, and morphology of the dark material are consistent with mill scale, or a mixture of mill scale and corrosion.

\subsection{SOLID PHASE CHARACTERIZATION ANALYSIS OF 2AY-12-ANU3 (S12T021354/S12R000529) AND 2AY-12-ANU5 (S12T021355/S12R000531)}

Two more samples, taken from material near Riser 90, were received at 222-S on October 15, 2012. The samples were collected with the remotely operated, mobile sampler developed by AREVA (RPP-PLAN-53352). These were examined by XRD and SEM using the abovereferenced procedures. Analysis by PLM was not conducted on these samples. Samples 2AY-12-ANU3 (S12T021354/S12R000529) (Figure 21) and 2AY-12-ANU5 (S12T021355/S12R000531) (Figure 22) had very limited sample material, and the bulk of the material was composed of iron oxide/hydroxide. 
Figure 21. Binocular Microscope Photomicrograph of Sample 2AY-12-ANU3, S12R000529.

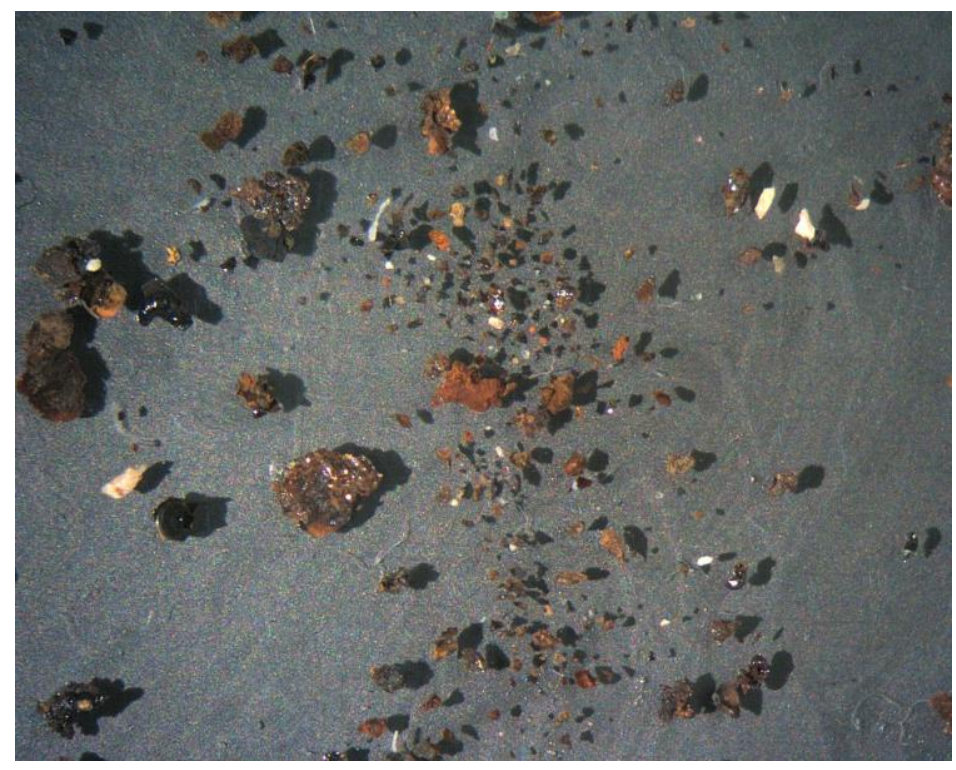

Figure 22. Binocular Microscope Photomicrograph of Sample 2AY-12-ANU5, S12R000531.

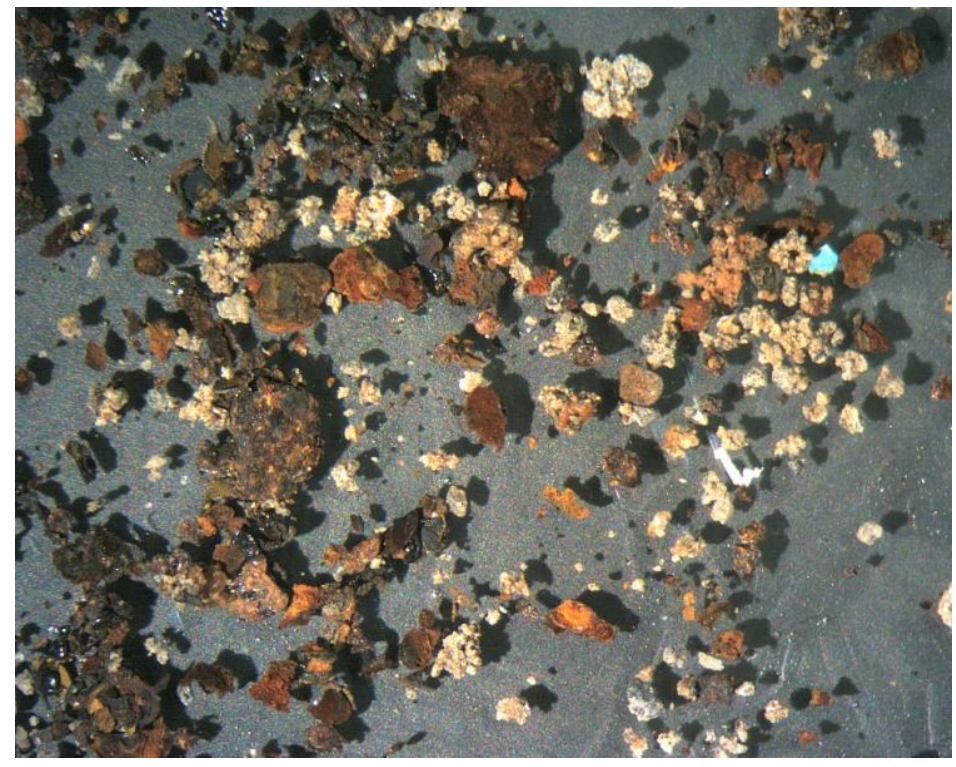

In addition to the iron-rich material, sodium carbonate was identified in the SEM analysis of Sample 2AY-12-ANU3 (S12R000529). Sodium nitrate/nitrite and sodium carbonate were both observed in the SEM analysis of 2AY-12-ANU5 (S12R000531).

In addition to the iron- and sodium-bearing material, both samples showed some silicate-rich particulate on the SEM. Figure 23 is a SEM image and EDS spectrum for quartz. 
Figure 23. Scanning Electron Microscopy Image and Energy Dispersive X-ray Spectrometry Spectrum of Sample S12R000531 (2AY-12-ANU5).
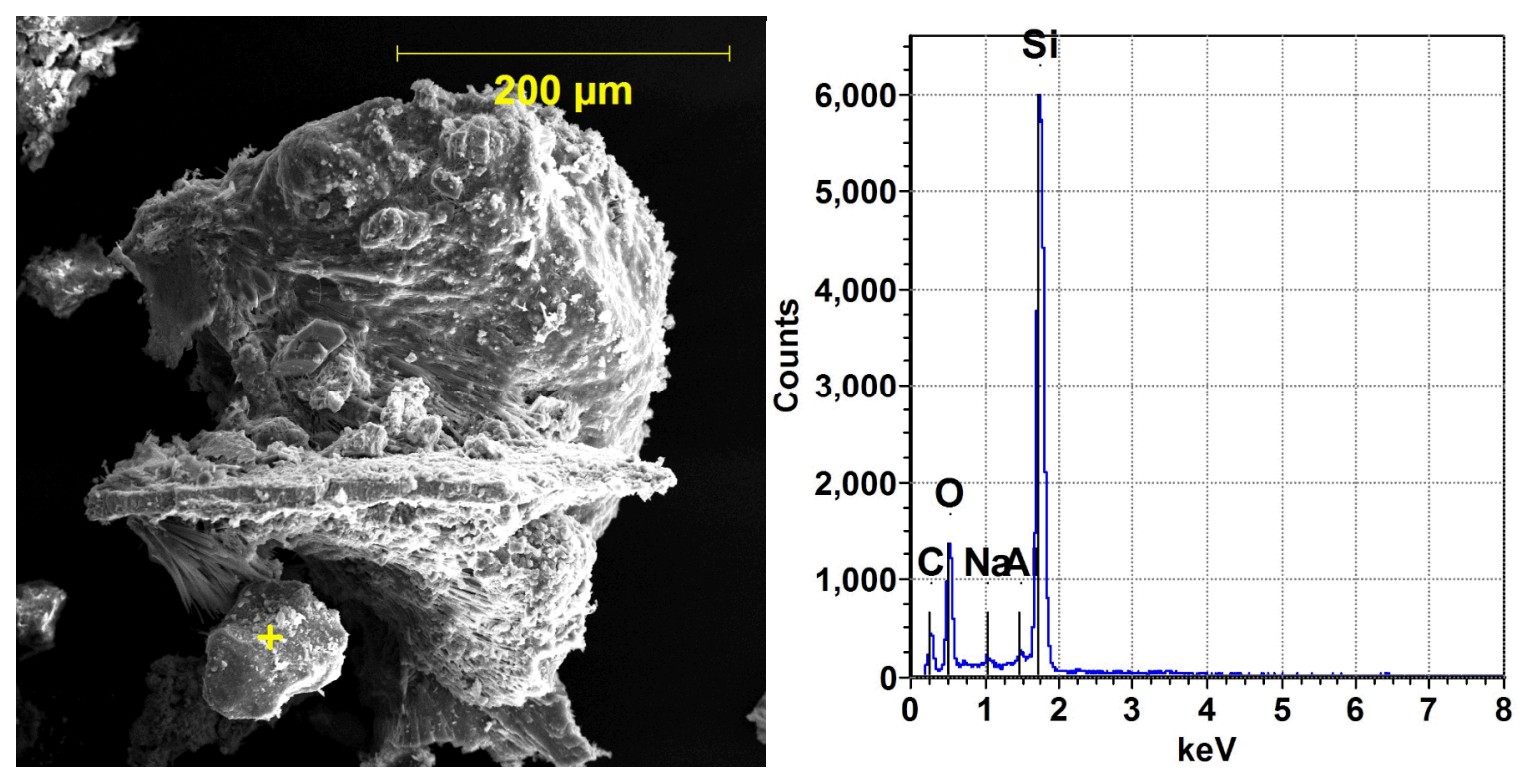
The XRD analysis was able to confirm the presence of sodium nitrite in 2AY-12-ANU5 (Figure 24). Figure 24 is the XRD pattern for Sample S12R000531. In addition to the diffraction pattern, the reference spectra for sodium nitrate, quartz, and the feldspar mineral albite are also shown. Quartz and feldspar are the most common minerals in Hanford soil. There were no significant peaks in the XRD spectrum for 2AY-12-ANU3.

Figure 24. X-ray Diffraction Pattern for Sample 2AY-12-ANU5 (S12R000531).

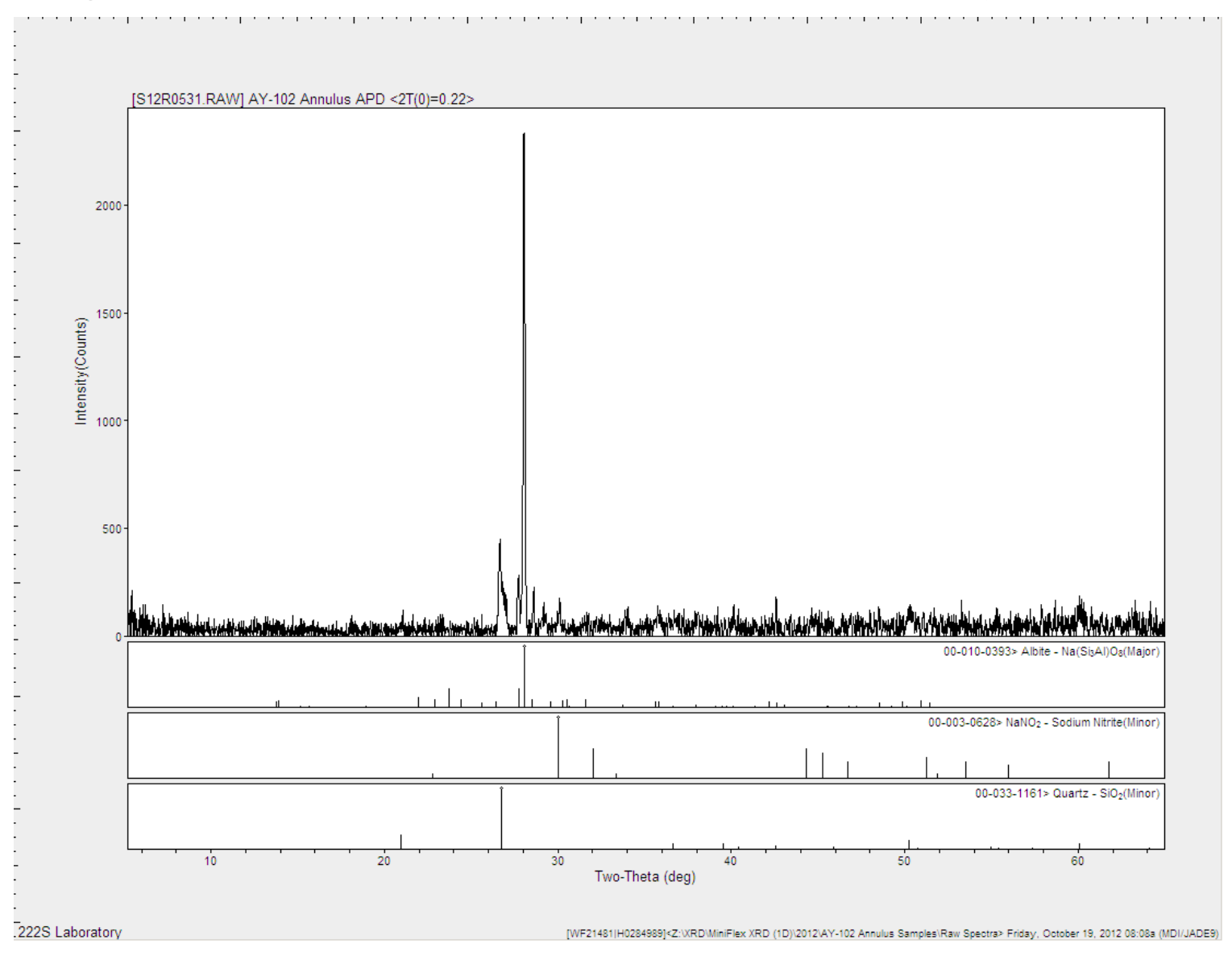


Finally, a single patch of an iron sulfate was seen in the SEM analysis of S12R000531 (2AY-12 ANU5) (Figure 25).

Figure 25. Scanning Electron Microscopy Image and Energy Dispersive X-ray Spectrometry Spectrum of Sample S12R000531 (2AY-12-ANU5).
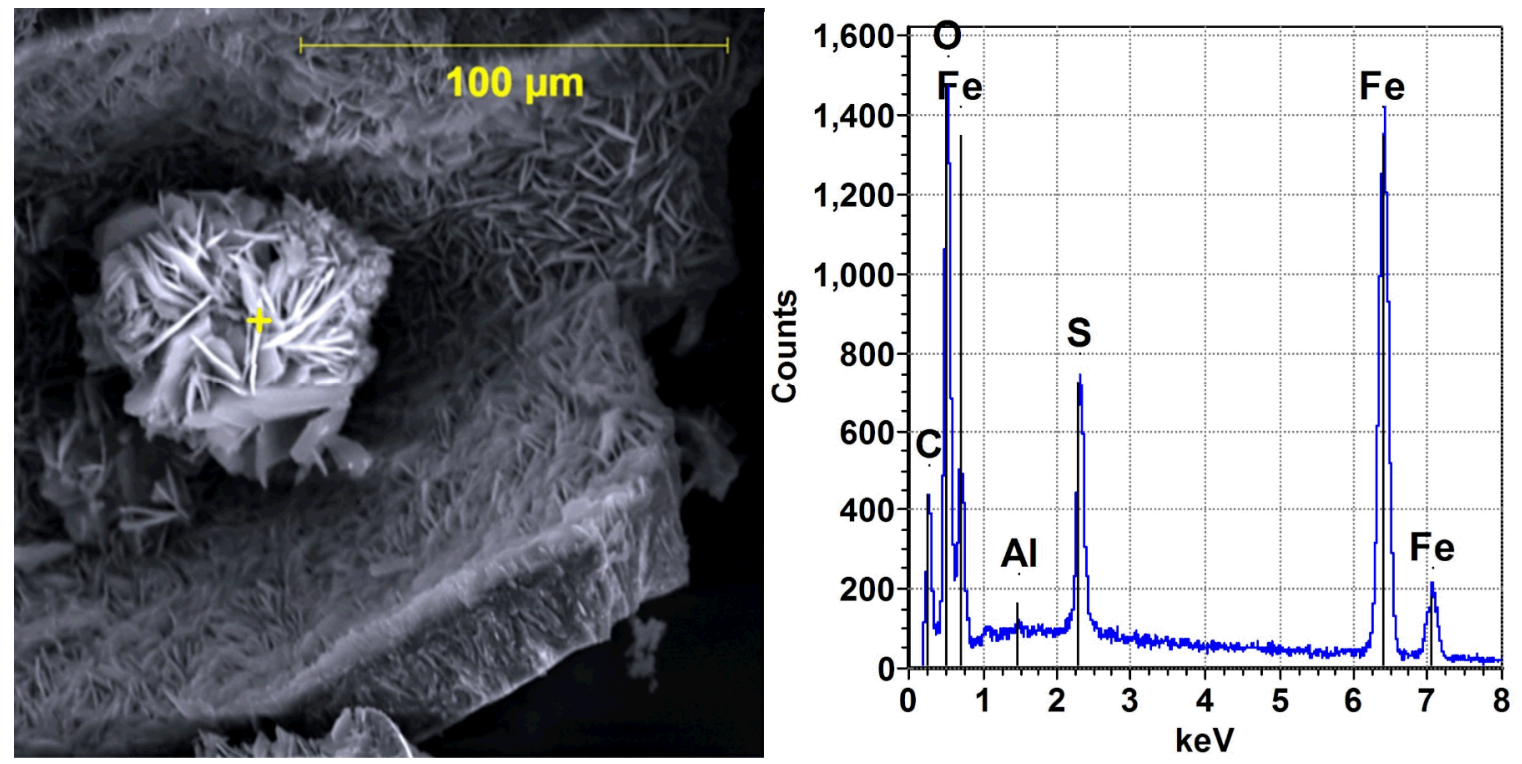

\subsection{SOLID PHASE CHARACTERIZATION ANALYSIS OF 2AY-12-ANU3A (S12T021346/S12R000533) AND 2AY-12-ANU5A (S12T021356/S12R000534)}

The final two samples described in this report were received at the 222-S Laboratory on October 17, 2012. These samples were also taken near Riser 90 using the AREVA mobile sampler. The samples, identified as 2AY-12-ANU3A and 2AY-12-ANU5A, were examined in the 11A hot cells, photographed, weighed, transferred to glass jars, and transferred to the contamination area portion of the lab. The samples were again photographed in the lab prior to analysis.

Prior to sub-sampling, all the sample material was poured into a 2-in. diameter Petri dish. Macrophotographs and photomicrographs were taken of this material. Figures 26 and 27 show representative macrophotographs and photomicrographs of the two samples. Both samples appear to be mixtures of light colored aggregates along with dark reddish-brown material that is assumed to be a mix of rust and mill scale. Sample 2AY-12-ANU3A is primarily composed of light colored particulate, while Sample 2AY-12-ANU5A consists primarily of rust and scale. 
Figure 26. Optical Images of 2AY-12-ANU3A. Petri Dish is 2 Inches in Diameter.

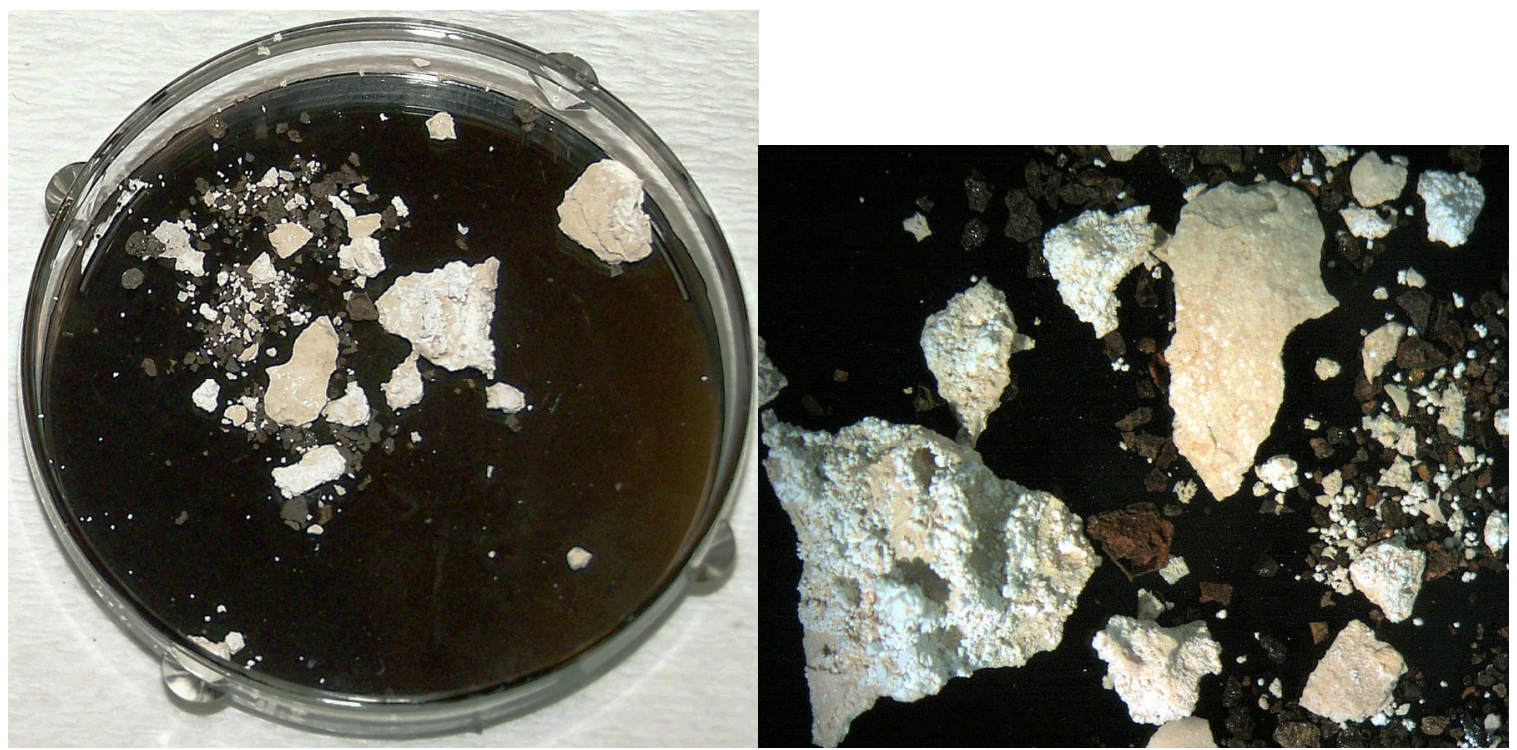

Figure 27. Optical Images of 2AY-12-ANU5A. Petri Dish is 2 Inches in Diameter.
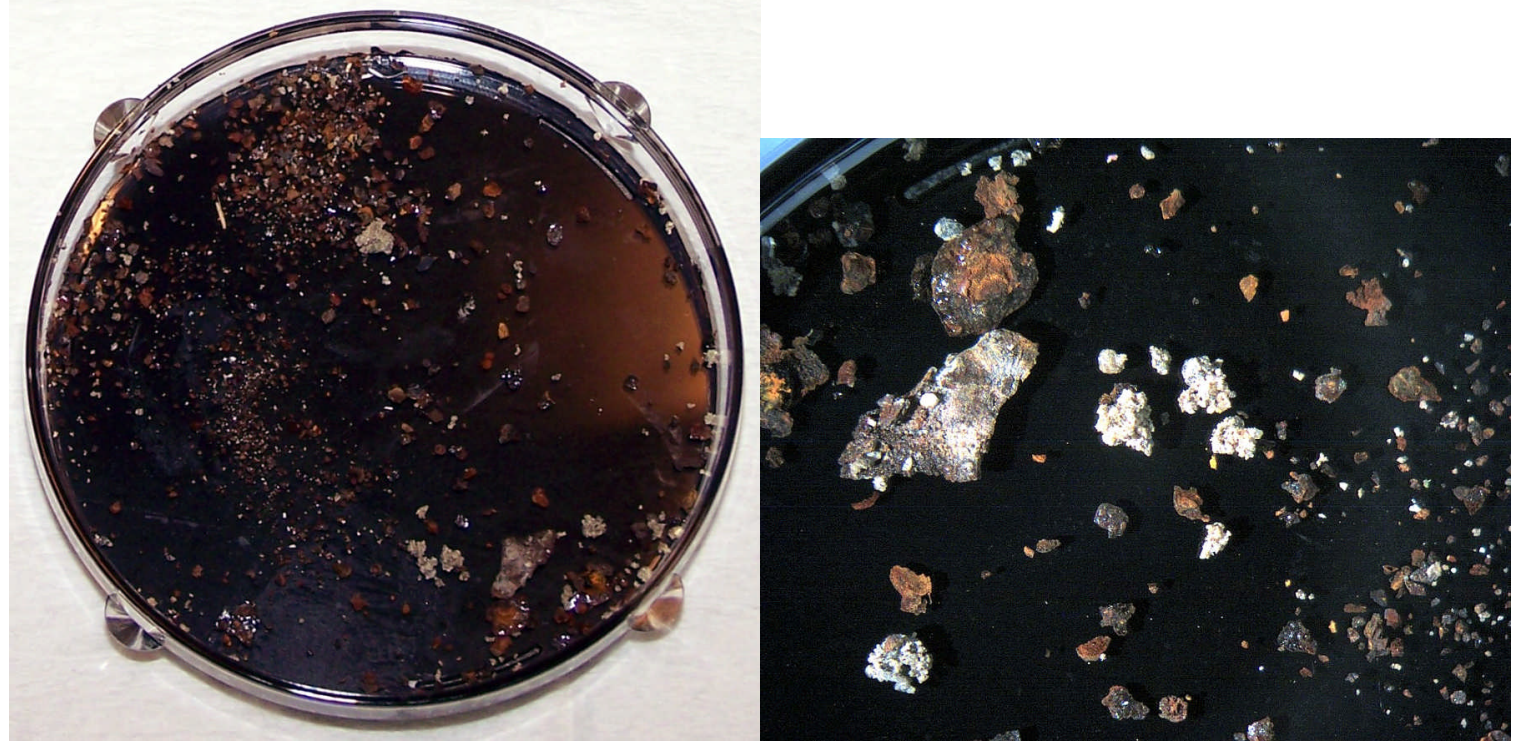

Close-up optical images of some of the white particulate in both samples show that they consist primarily of aggregates of smaller particles. In the case of the 2AY-12-ANU3A sample, these appear to be aggregates of salt crystals, either botryoidal (Figure 28), lath- or blade-like (Figure 29), or glassy and vesicular (Figure 30). These appear to be at least two different salt crystals. The glassy vesicular surface appears to have been at the surface of the air slot sample and to have crystallized in the presence of gas bubbles. 
Figure 28. Aggregate of Salt Crystals Showing Botryoidal Morphology, Sample 2AY-12-ANU3A.

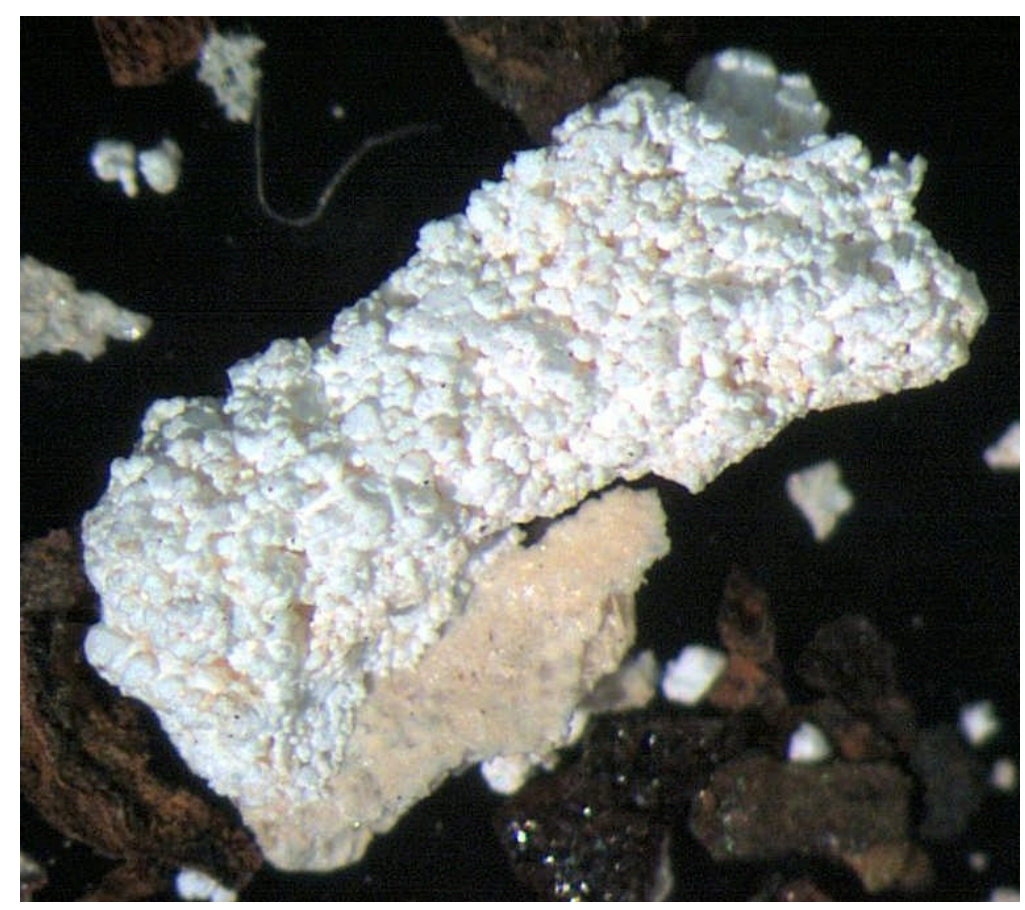

Figure 29. Aggregate of Salt Crystals Showing Blade- or Lath-like Morphology, Sample 2AY-12-ANU3A.

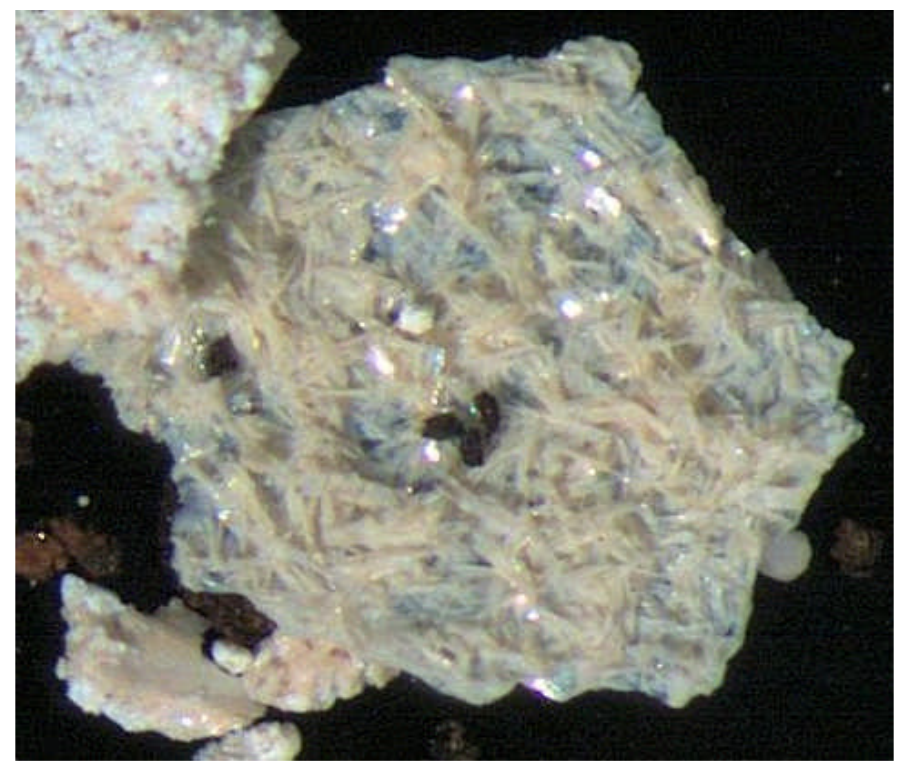


Figure 30. Aggregate of Salt Crystals Showing Glassy and Vesicular Morphology, Sample 2AY-12-ANU3A.

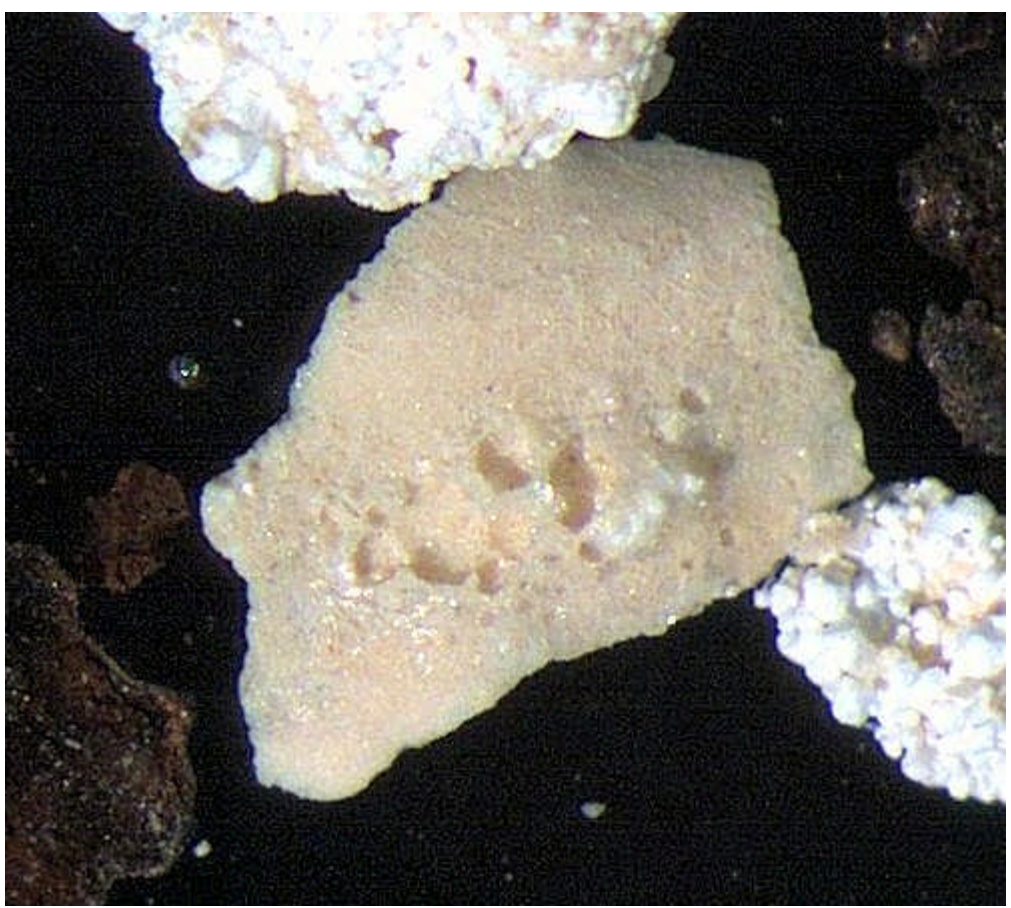

The light colored particulate in Sample 2AY-12-ANU5A was much rarer than in 2AY-12-ANU3A. The light colored particulate in 2AY-12-ANU5A appears to be aggregates of darker material cemented by white salt (Figure 31).

Figure 31. Aggregate of Light and Dark Colored Particulate, Sample 2AY-12-ANU5A.

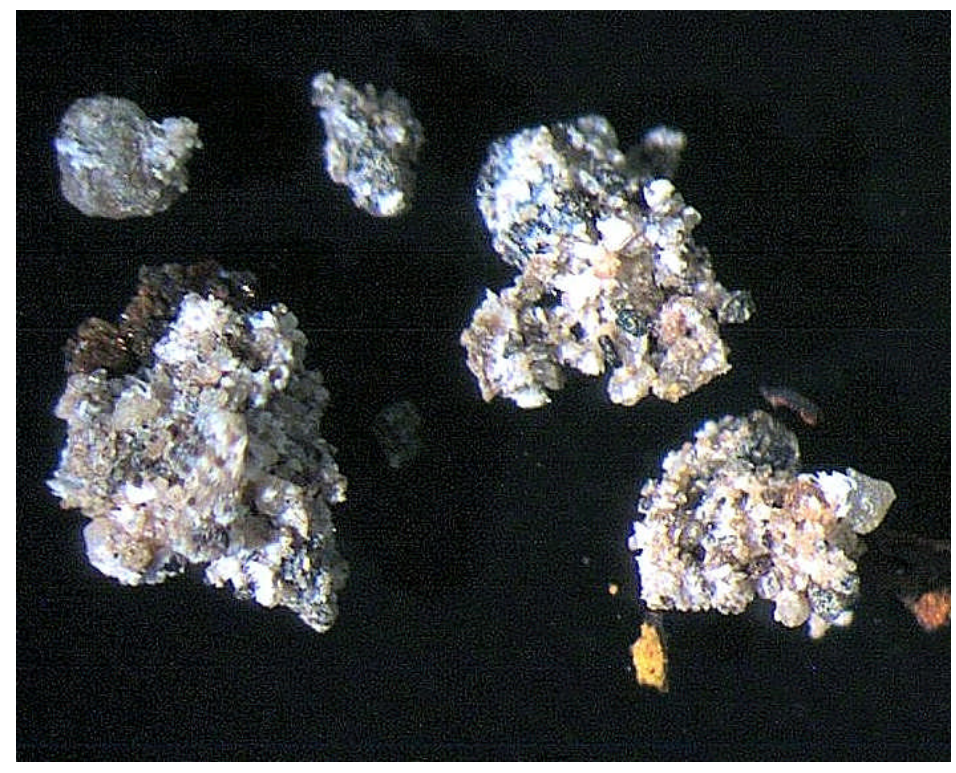


The white pieces were separated from Sample 2AY-12-ANU3A and crushed. The XRD and SEM splits were removed from this crushed material. A portion of the crushed split that was analyzed by XRD was also examined by PLM. The remaining ground white material was placed in a pre-weighed $60-\mathrm{ml}$ plastic bottle and given to Analytical Technologies and Laboratories International, Inc. personnel for gamma energy analysis (GEA). Approximately $0.1 \mathrm{~g}$ was available for this analysis.

The 2AY-12-ANU5A sample was crushed in its entirety. No attempt was made to separate the rust from the few light colored fragments that were present. Analysis by XRD, SEM, and PLM was conducted on this material.

\subsubsection{Solid Phase Characterization of Sample 2AY-12-ANU3A}

The white particulate from Sample 2AY-12-ANU3A (S12R000533) consists entirely of water soluble salts that are consistent with tank waste saltcake or supernatant dissolved solids. However, there are some notable differences between this material and the previous tank waste material that has been retrieved from the AY-102 annulus.

Sample 2AY-12-ANU3A consisted of dry white solid aggregates with a minor amount of reddish-brown particles. The sample weighed $0.20 \mathrm{~g}$. The light colored particulate was separated from the reddish-brown rust and scale. This light-colored material was crushed in an agate mortar and pestle and sub-sampled for SPC. Prior to complete crushing, several pieces were removed and reserved for SEM analysis. A portion of the crushed powder was transferred to an adhesive carbon tab mounted on an SEM planchet. The fine particulate was pressed into place, and the larger particulate was added and also pressed into the adhesive surface. For XRD analysis, a portion of the completely ground material was placed in the well of a zero background mount, compressed with a glass slide, and fixed with a collodion binder. A portion of the crushed sample was examined by PLM. The PLM specimen was prepared by transferring a small amount of the dry powder onto a glass slide, adding a drop of oil with a 1.55 index of refraction.

Analysis by XRD revealed a series of strong peaks. Nearly all of them could be attributed to crystalline phases that are consistent with tank waste salts. The following phases and relative abundances were found.

Table 2. X-ray Diffraction Results for Sample 2AY-12-ANU3A (S12R000533).

\begin{tabular}{|l|l|l|l|}
\hline \multicolumn{1}{|c|}{ Chemical Name } & \multicolumn{1}{c|}{ Mineral Name } & \multicolumn{1}{c|}{ Formula } & \multicolumn{1}{c|}{ Relative Amount } \\
\hline Sodium Carbonate Anhydrous & Natrite & $\mathrm{Na}_{2} \mathrm{CO}_{3}$ & Major \\
\hline Sodium Hydrogen Phosphate & Nahpoite & $\mathrm{Na}_{2} \mathrm{HPO}_{4}$ & Minor \\
\hline Sodium Nitrite & - & $\mathrm{NaNO}_{2}$ & Minor \\
\hline Sodium Oxalate & Natroxalate & $\mathrm{Na}_{2} \mathrm{C}_{2} \mathrm{O}_{4}$ & Minor \\
\hline
\end{tabular}

The SEM analysis confirmed the presence of a phase consistent with the anhydrous sodium carbonate (Figure 32). As before, this figure and the other SEM images are paired with an EDS spectrum taken from the area marked with the yellow + . This phase is responsible for the bladeand lath-like crystals observed in the optical microscope (Figure 29). Sodium carbonate is 
present in tank waste. However, it is found as the monohydrate phase, thermonatrite $\left(\mathrm{Na}_{2} \mathrm{CO}_{3} \cdot \mathrm{H}_{2} \mathrm{O}\right)$. Apparently, the temperature near this sample was high enough to dehydrate the normally hydrated sodium carbonate or to allow the anhydrous form to precipitate directly. This is consistent with an elevated temperature.

Figure 32. Sodium Carbonate Laths, Sample 2AY-12-ANU3A (S12R000533).
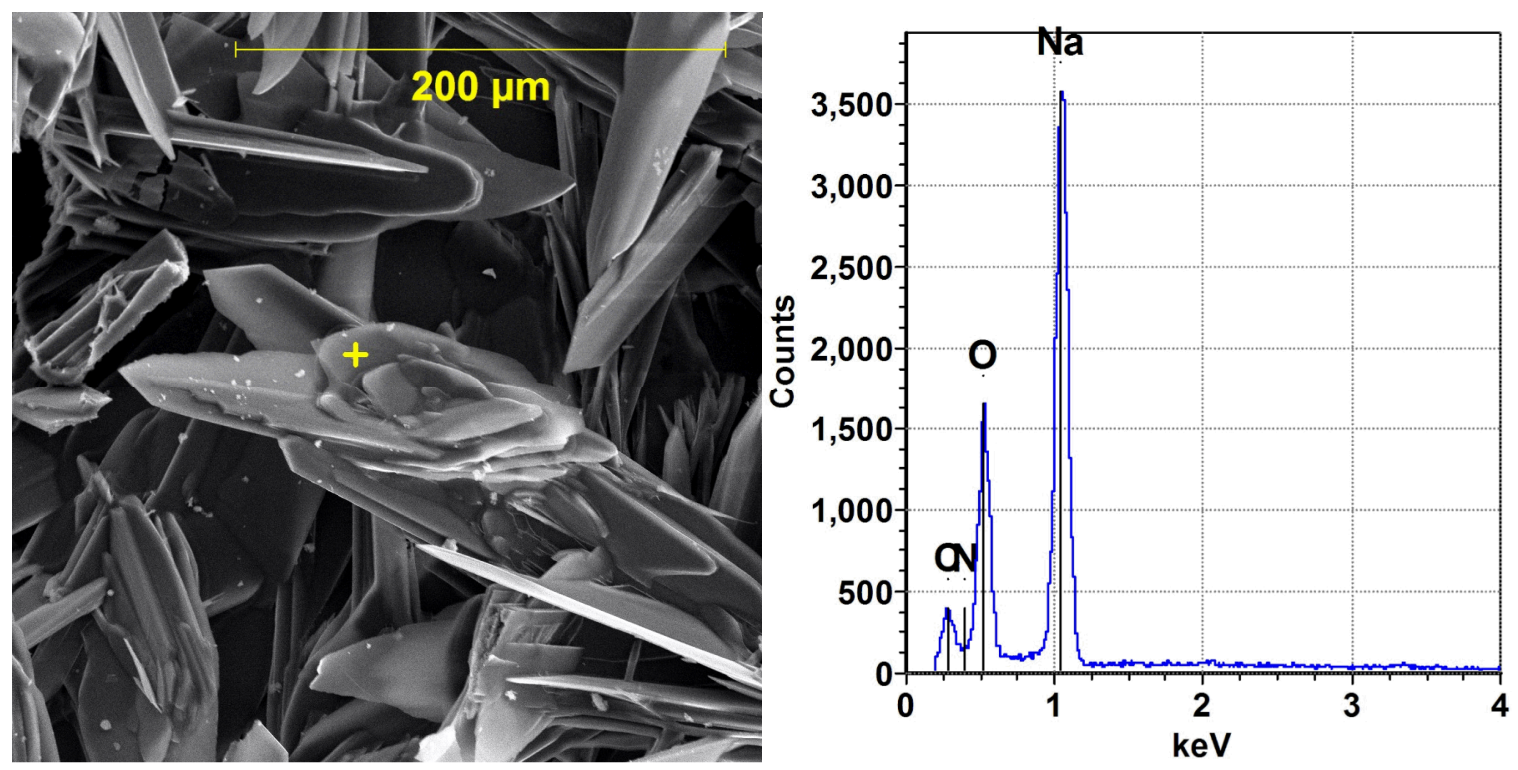

The SEM could not confirm the sodium nitrite that was observed in the XRD scan. The nitrogen peak is particularly insensitive, and there needs to be a nearly pure sodium nitrite before the peak can be observed on the EDS spectrum. The presence of an elevated background where the nitrogen peak is located could be seen on many of the EDS spectra, but never a discrete peak.

The phase identified as nahpoite $\left(\mathrm{Na}_{2} \mathrm{HPO}_{4}\right)$ in the XRD pattern was not observed in the SEM specimen. Instead, equant octahedral crystals with the appearance and the EDS spectra consistent with the common tank waste phase, natrophosphate $\left(\mathrm{Na} 7 \mathrm{~F}\left(\mathrm{PO}_{4}\right)_{2}-19 \mathrm{H}_{2} \mathrm{O}\right)$, was seen (Figure 33). However, the SEM image shows crystals that are pock-marked and pitted. This would be consistent with dehydration. 
Figure 33. Sodium Fluoride Phosphate, Sample 2AY-12-ANU3A (S12R000533).
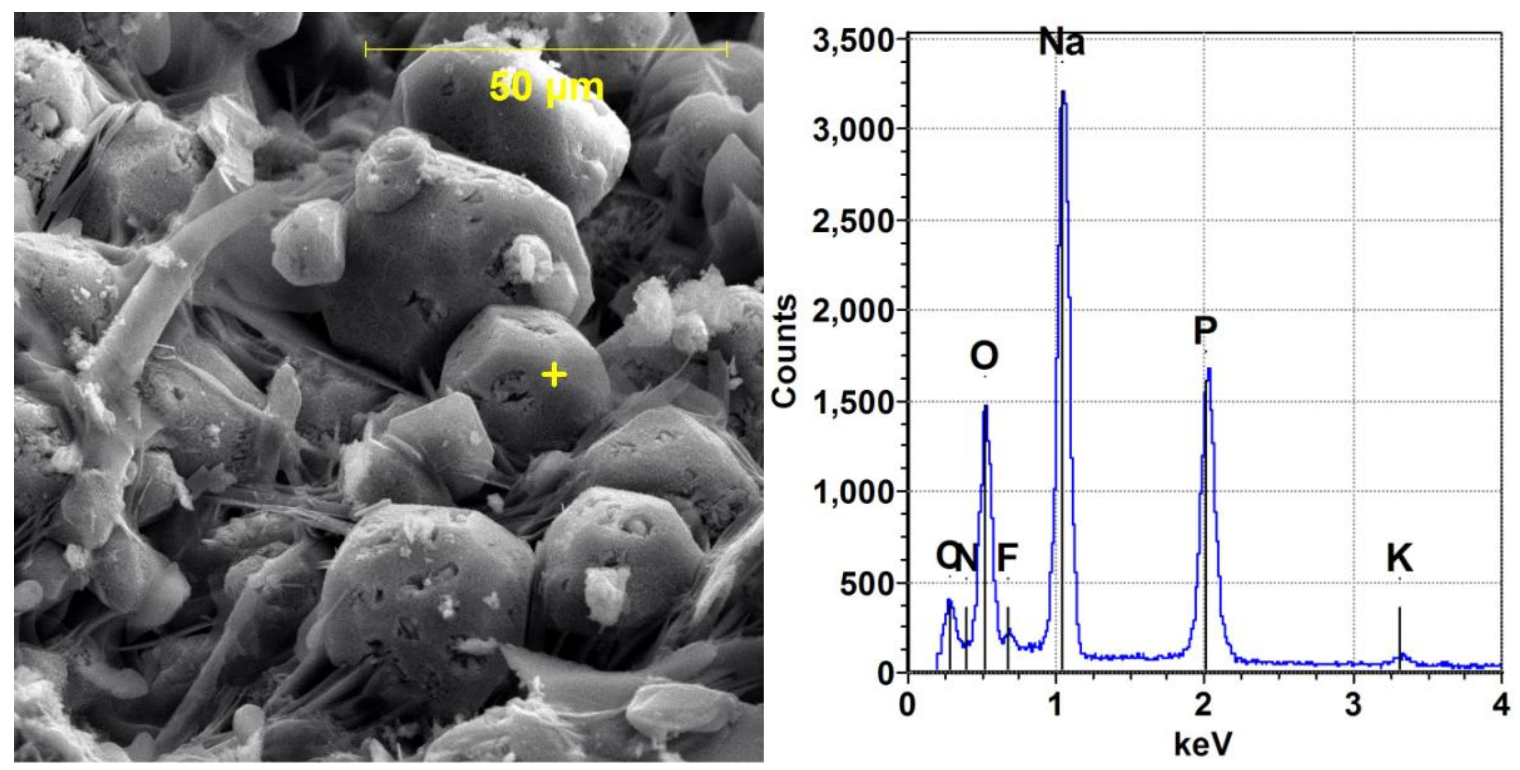

Little is known about the dehydration of this phase. The lack of reference information on the anhydrous $\left(\mathrm{Na}_{7} \mathrm{~F}\left(\mathrm{PO}_{4}\right)_{2}\right.$ suggests that it is rare or non-existent. It appears that eventually the phase will dehydrate and recrystallize as the simple salts $\mathrm{NaF}$ and $\mathrm{Na}_{3} \mathrm{PO}_{4}$. The SEM and XRD results here can be reconciled if the dehydrated phase(s) are amorphous, and the sample contains $\mathrm{Na}_{2} \mathrm{HPO}_{4}$, unseen on the SEM but identified in the XRD sample. If so, this would suggest a more neutral $\mathrm{pH}$ than the 2AY-12-ANU1 sample from the floor of the annulus. Alternatively, there could be an intermediate dehydrated phase with the composition $\mathrm{Na}_{7} \mathrm{~F}\left(\mathrm{PO}_{4}\right)_{2}$ that has a crystalline structure identical to the $\mathrm{Na}_{2} \mathrm{HPO}_{4}$.

No evidence of the sodium oxalate was observed in the SEM. However, that phase cannot be chemically distinguished from the sodium carbonate on the EDS spectra. Therefore, the identification of sodium oxalate in the SEM relies on slight differences in the morphology. No crystals with a morphology consistent with sodium oxalate were observed.

Polarized light microscopy of this sample revealed the coarser particulate to be composed of fine crystallites (Figure 34). The PLM analysis was able to confirm the presence of sodium oxalate and found a trace amount of gibbsite $\left(\mathrm{Al}(\mathrm{OH})_{3}\right)$. Gibbsite was not observed in the XRD and SEM analysis. The fine-grained aggregate nature of the larger particles lends credence to the decomposition of the sodium fluoride phosphate into $\mathrm{NaF}$ and $\mathrm{Na}_{3} \mathrm{PO}_{4}$. 
Figure 34. Polarized Light Microscopy Images with Crossed Polarizers and the Red Compensation Plate, Sample 2AY-12-ANU3A (S12R000533).
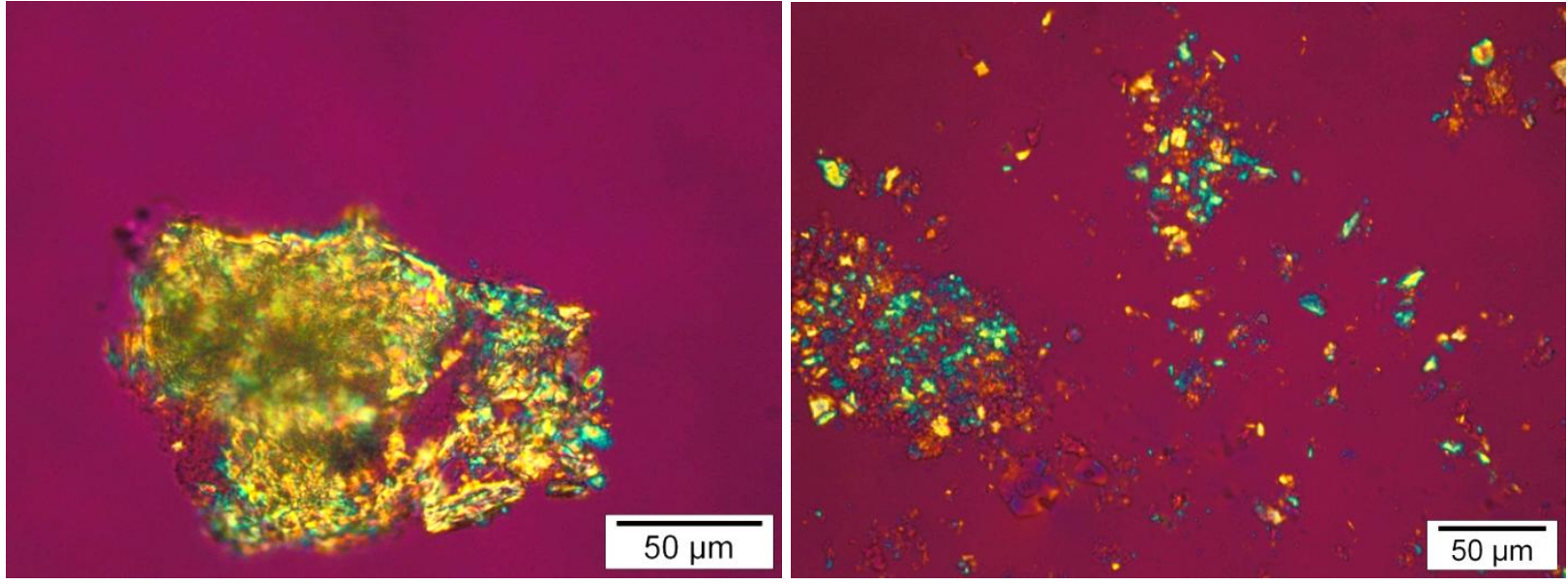

While there appeared to be some potassium in the sample, there was no evidence of a discrete potassium nitrate phase, as had been seen on the tape samples or the floor sample (2AY-12-ANU1 white). The highest concentration of potassium observed in the EDS spectra was from a particle that was largely obscured by sodium carbonate laths (Figure 35).

Figure 35. Minor Potassium Peak in Energy Dispersive X-ray Spectrometry Spectrum, Sample 2AY-12-ANU3A (S12R000533).
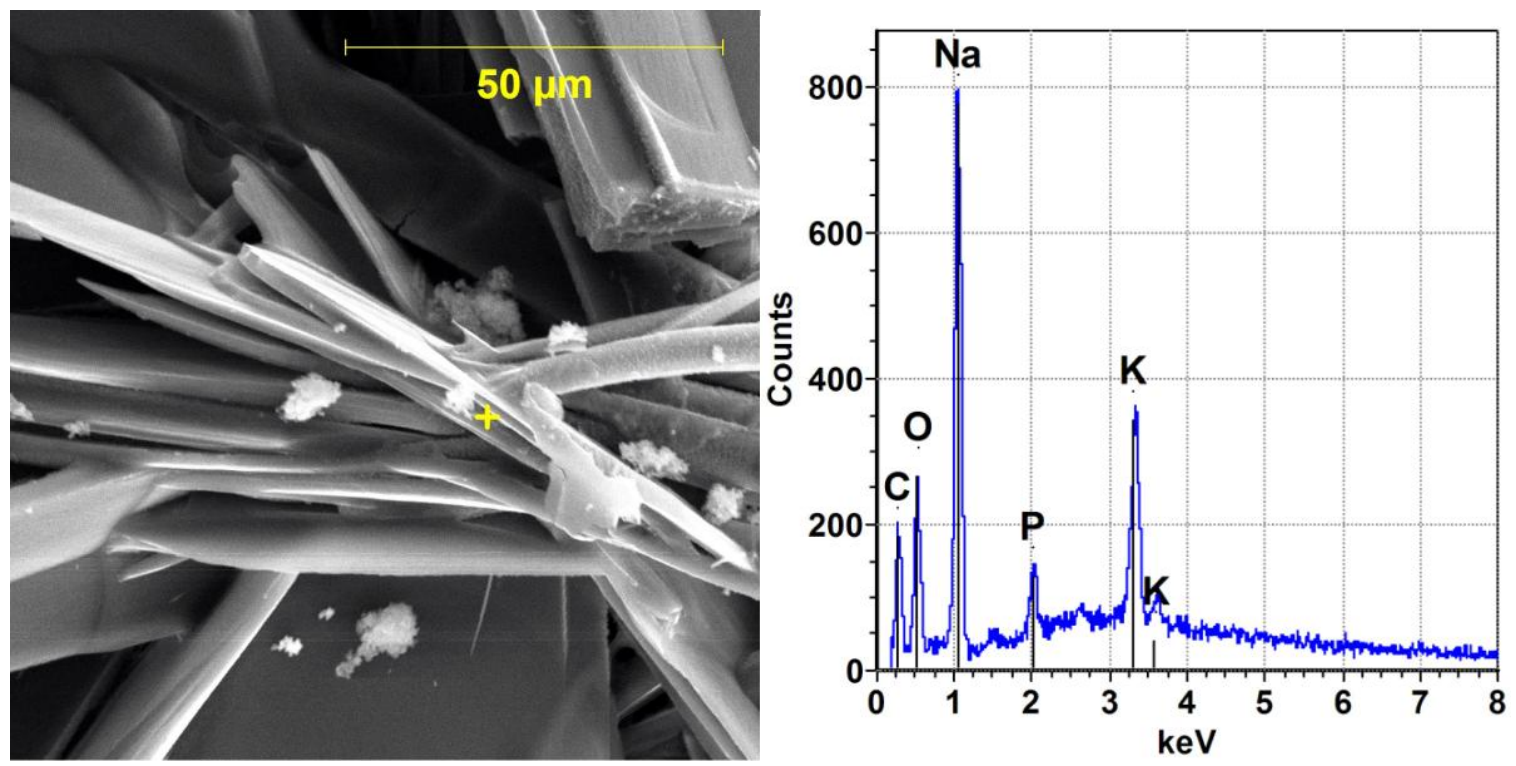


\subsubsection{Solid Phase Characterization of Sample 2AY-12-ANU5A}

The particulate from Sample 2AY-12-ANU5A (S12R000534) was seen on the SEM to consist of a mixture of rust and soil with a small amount of a sodium-rich phase. The XRD pattern for this sample showed no significant peaks for any crystalline phase.

The 2AY-12-ANU5A sample weighed only $0.12 \mathrm{~g}$ and was crushed in its entirety. No attempt was made to separate the rust from the few light colored fragments that were present. Analysis by XRD and SEM was conducted on this material, consuming nearly the entire sample. As a result of our preliminary examination, we recommended that this sample be examined by PLM as well.

The particulate from Sample 2AY-12-ANU5A was seen on the SEM to consist predominantly of rust or mill scale (Figure 36). Soil particles are the next most abundant particle type. Figures 37 through 40 show particles with chemical compositions consistent with minerals found in Hanford soil or sand. There was also a small amount of a sodium-rich phase (Figure 41), and a single particle of a sodium sulfate was also seen (Figure 42).

The XRD pattern for this sample showed no significant peaks for any crystalline phase. This suggests that the crystalline mineral material and the sodium-rich phase (if crystalline) make up less than $20 \%$ of the sample. The diffraction peaks from these phases would be difficult to detect in the high-iron matrix of the sample. Visual estimates from the PLM and SEM sample preparations suggest that the rust/scale makes up 75 to $85 \%$ of the 12 -ANU5A sample.

The SEM sample specimen contained no detectible beta/gamma radiation using the room monitors. The only evidence for tank waste material in this sample was the sodium-rich particulate, estimated to make up about $5 \%$ of the SEM sample. The only source outside of tank waste that could provide a sodium-rich particulate is clean caustic. 
Figure 36. Scanning Electron Microscopy Image of Rust/Scale, Sample 12-ANU5A (S12R000534).
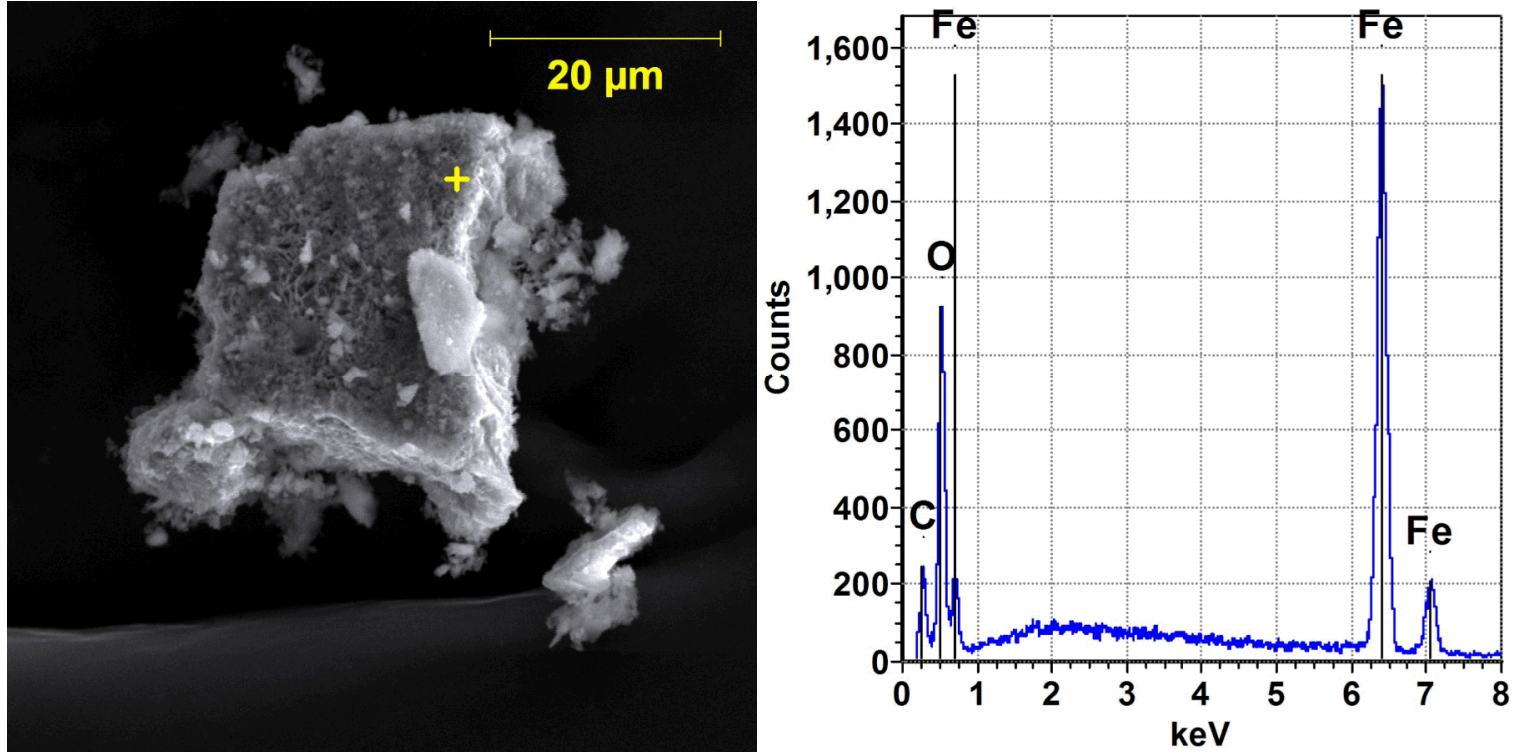

Figure 37. Scanning Electron Microscopy Image of Quartz, Sample 12-ANU5A (S12R000534).
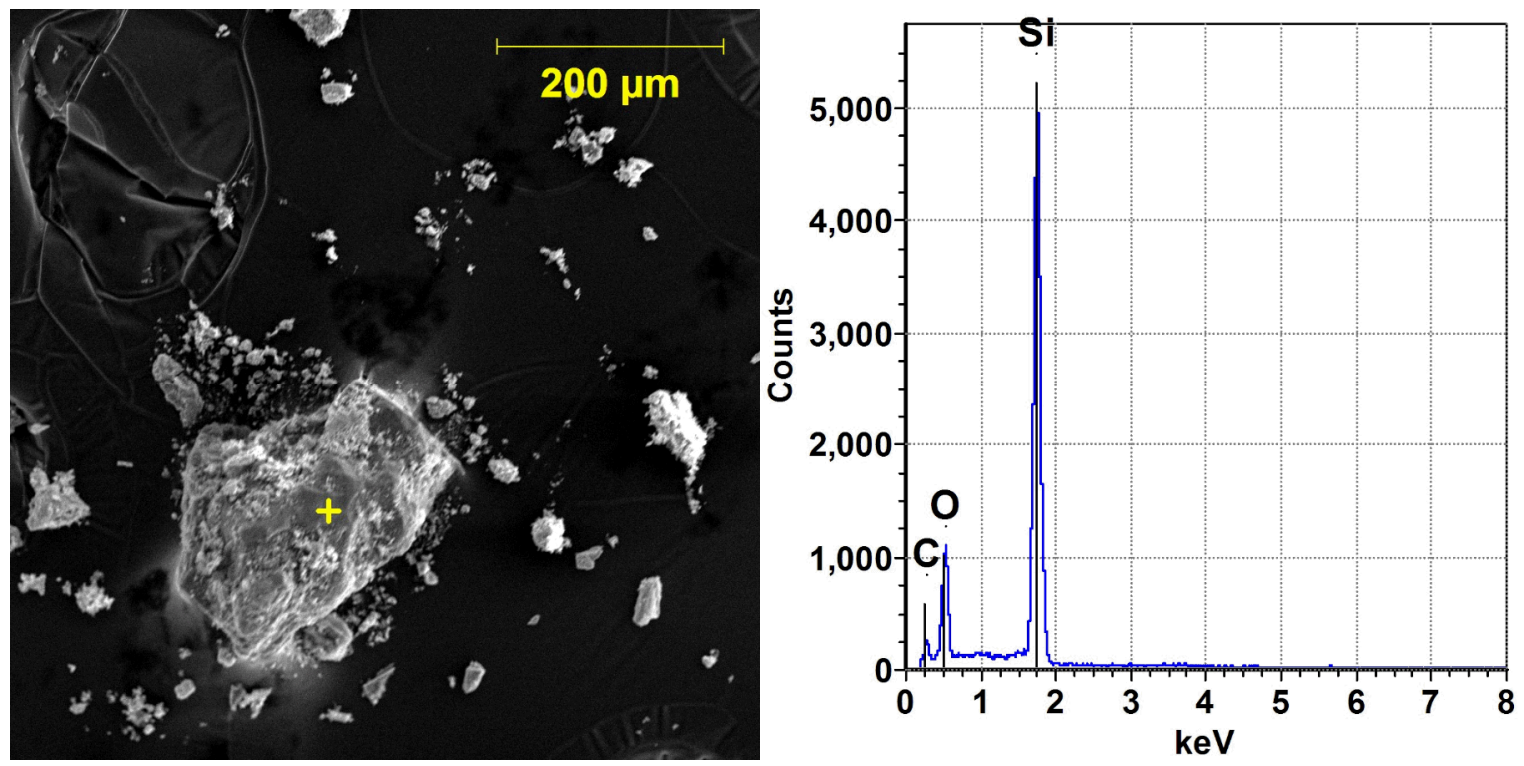
Figure 38. Scanning Electron Microscopy Image of Potassium Feldspar, Sample 12-ANU5A (S12R000534).
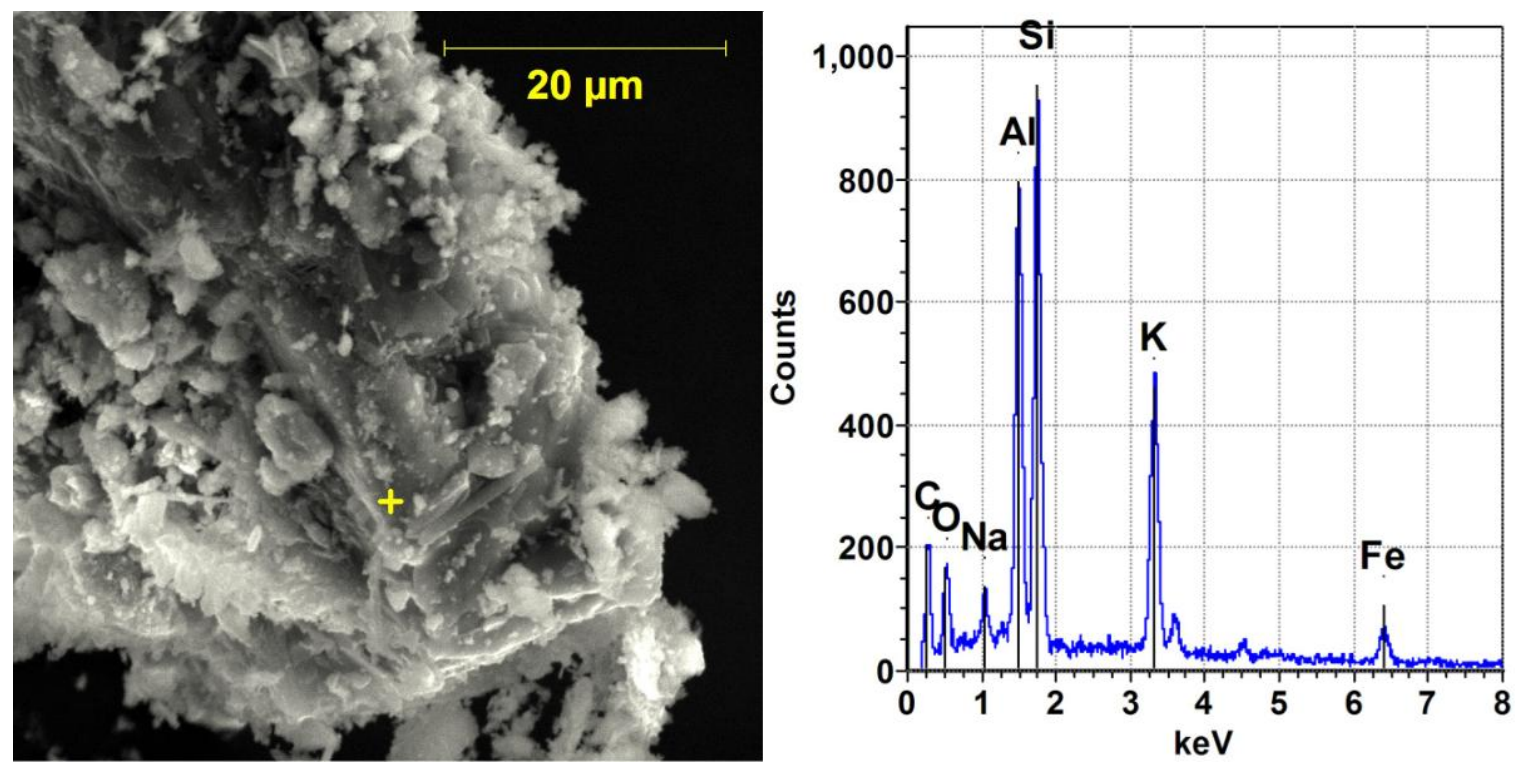

Figure 39. Scanning Electron Microscopy Image of Plagioclase Feldspar, Sample 12-ANU5A (S12R000534).
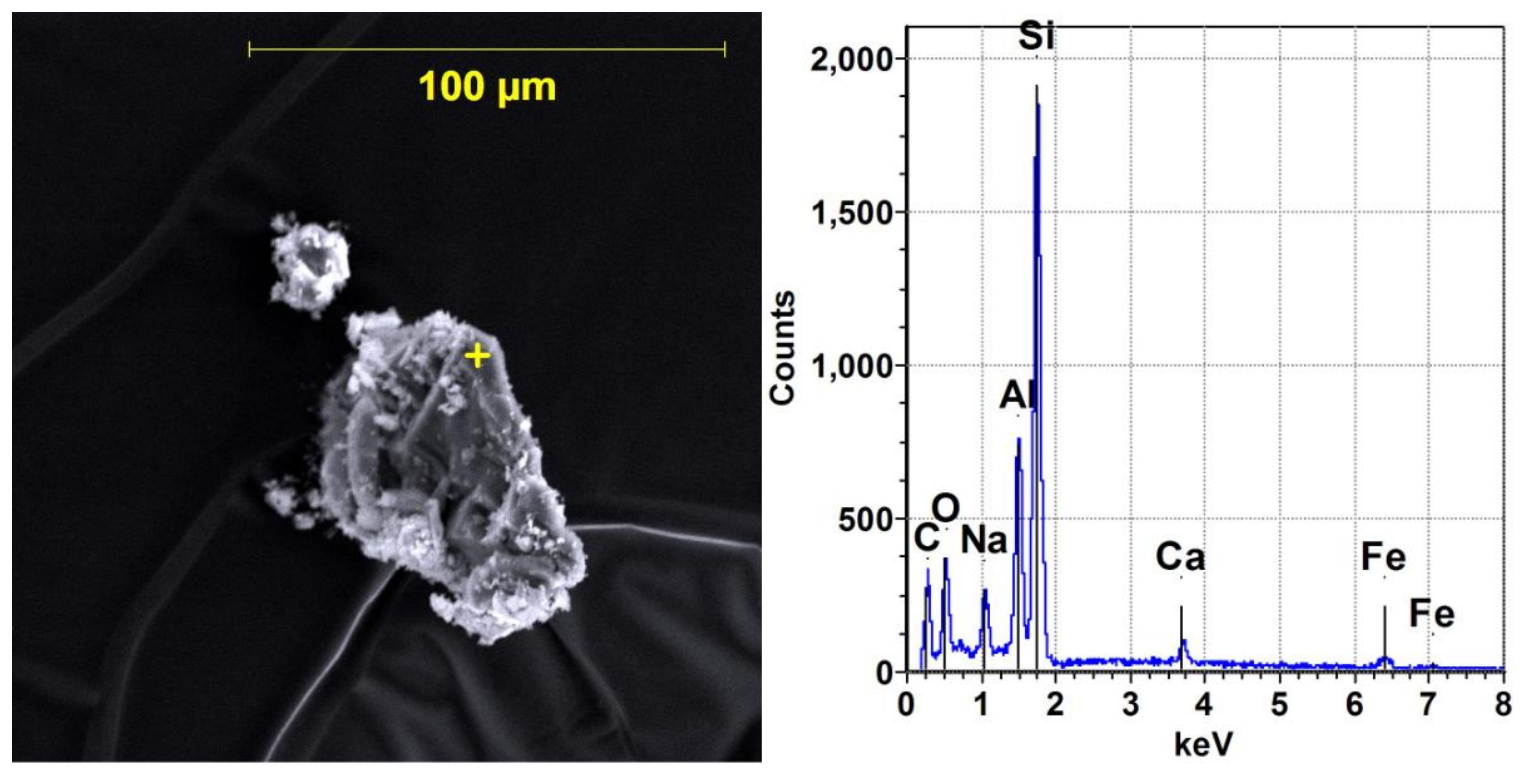
Figure 40. Scanning Electron Microscopy Image of Amphibole or Pyroxene, Sample 12-ANU5A (S12R000534).
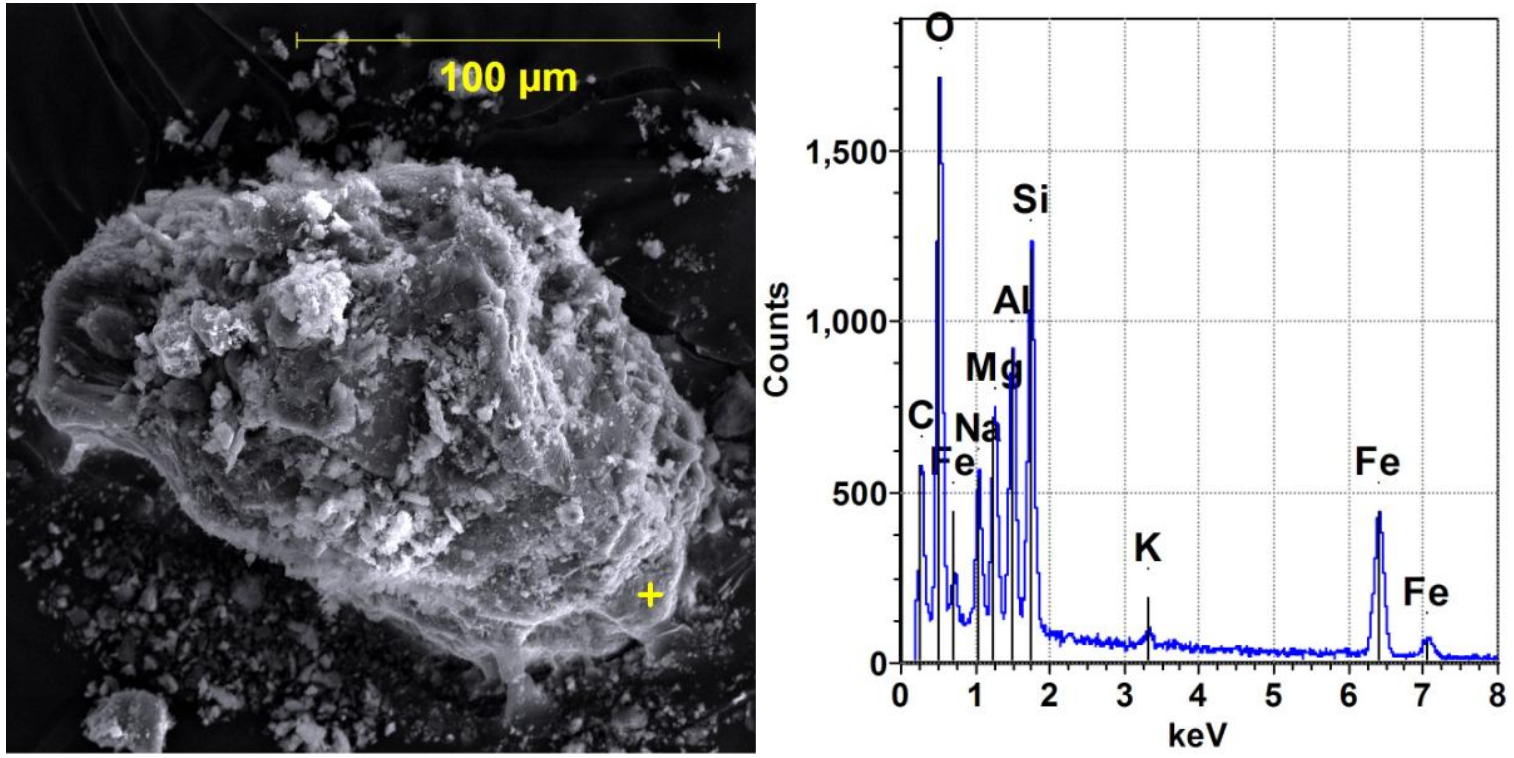

Figure 41. Scanning Electron Microscopy Image of Sodium-Rich Particulate, Sample 12-ANU5A (S12R000534).
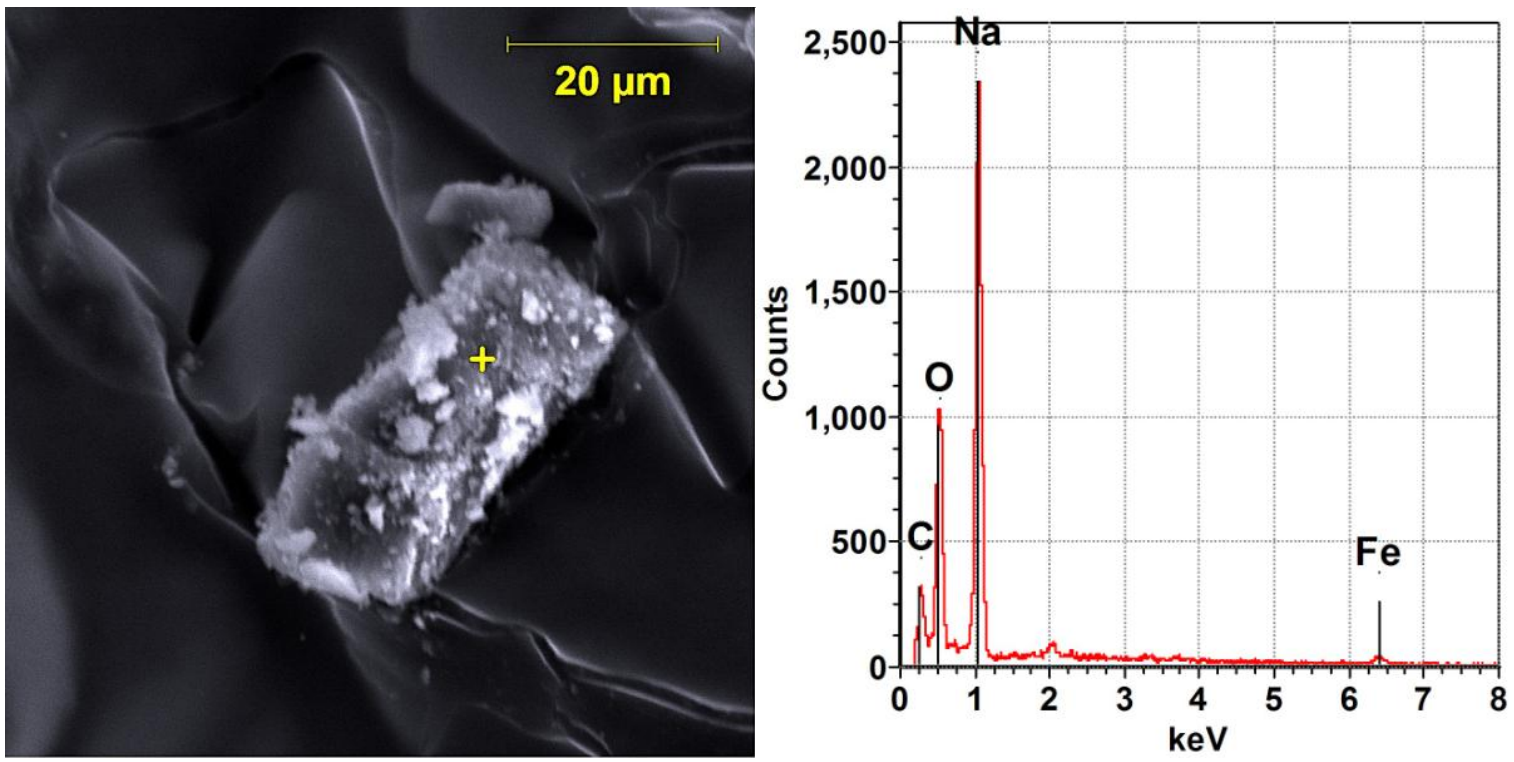
Figure 42. Scanning Electronic Microscopy Image of Sodium Sulfate Particulate, Sample 12-ANU5A (S12R000534).
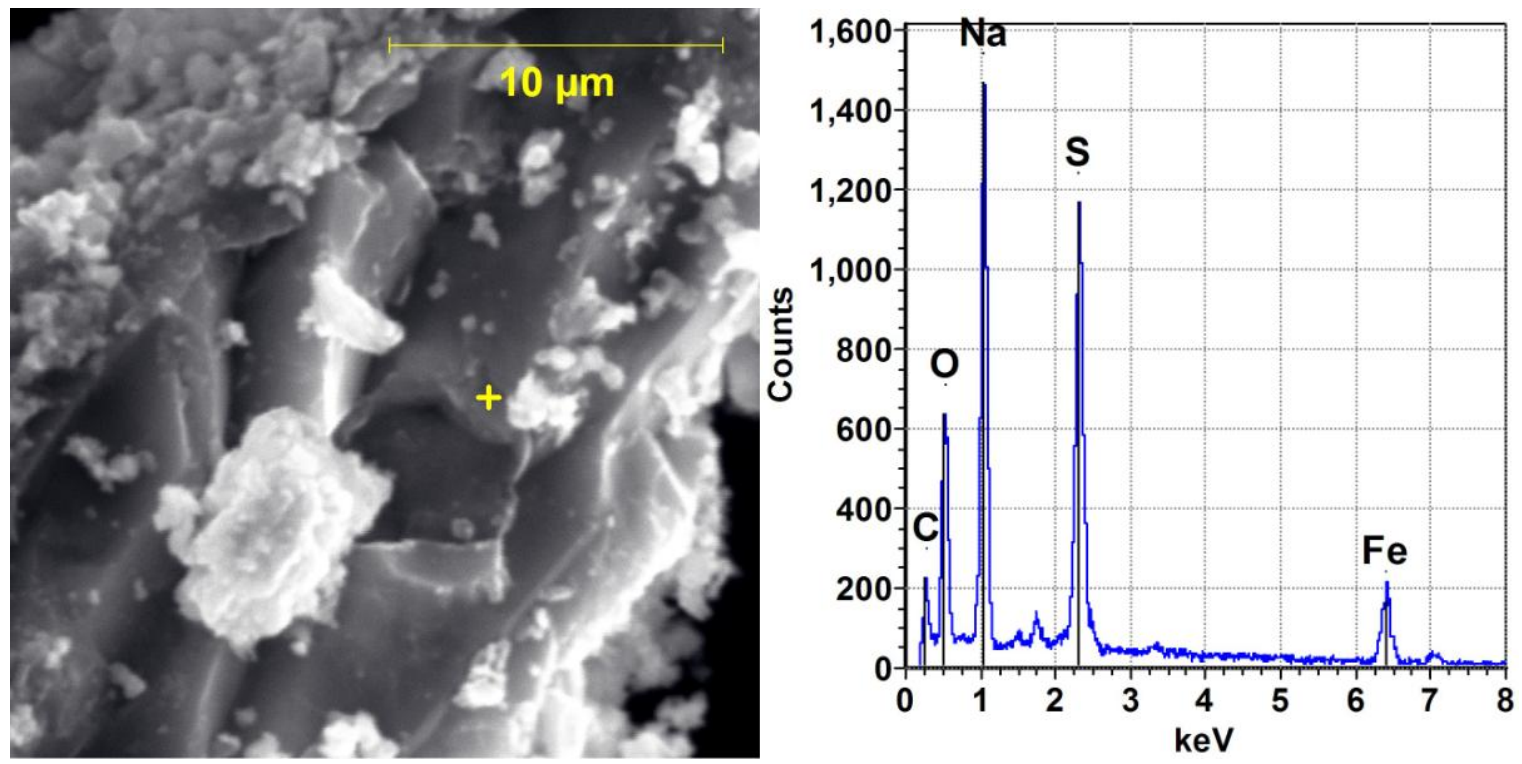

The PLM analysis indicated that the material was greater than $90 \%$ opaque (Figure 43). The remaining material was a fine-grained and birefringent particulate, consistent with ground soil.

Figure 43. Polarized Light Microscopy Image with Crossed Polarizers and the Red Compensation Plate, Sample 2AY-12-ANU5A (S12R000534).

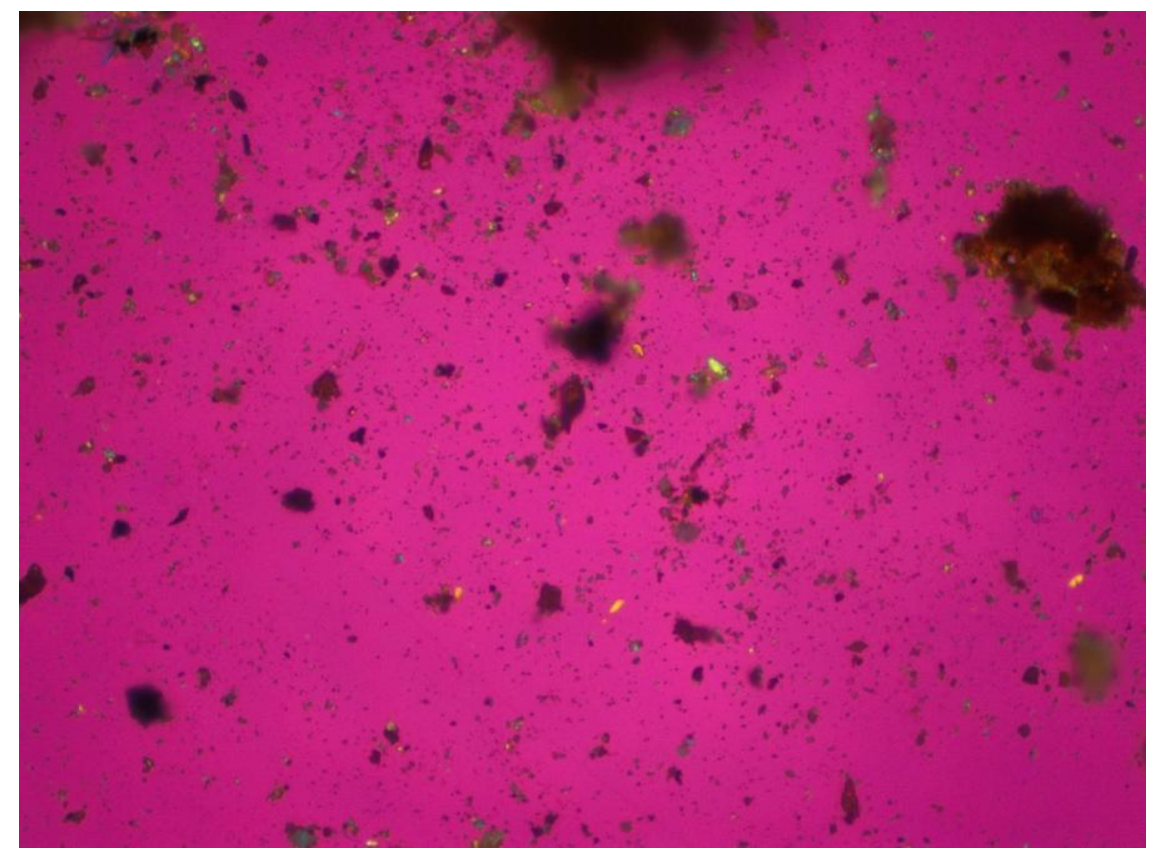




\section{LAB-RPT-12-00010 Rev. 0}

\section{DISCUSSION}

The swab samples from beneath Riser 90 contained at least three particle types: 1) rust or mill scale, 2) a blue-painted material with an aluminosilicate filler, and 3) tank waste. The tank waste in this sample had both sodium and potassium salts. The SEM analysis documents the presence of nitratine $\left(\mathrm{NaNO}_{3}\right)$, sodium phosphate dodecahydrate $\left(\mathrm{Na}_{3} \mathrm{PO}_{4} \bullet 12 \mathrm{H}_{2} \mathrm{O}\right)$, thermonatrite $\left(\mathrm{Na}_{2} \mathrm{CO}_{3} \cdot \mathrm{H}_{2} \mathrm{O}\right)$, and natrophosphate $\left(\mathrm{Na}_{7} \mathrm{~F}\left(\mathrm{PO}_{4}\right) 2 \cdot 19 \mathrm{H}_{2} \mathrm{O}\right)$ in the swab sample particulate. Except for the high potassium content, these phases are typical of saltcake and evaporated supernatant or interstitial liquid.

Potassium is generally rare in tank waste. However, the supernatant that currently resides in tank AY-102 is high in potassium (RPP-RPT-44630). This indicates that the supernatant is the source for the potassium observed in the tape sample.

The floor sample from near Riser 83 consisted of a mixture of rust/scale and the same potassiumbearing tank waste. The tank waste phases in this sample include thermonatrite $\left(\mathrm{Na}_{2} \mathrm{CO}_{3} \cdot \mathrm{H}_{2} \mathrm{O}\right)$, nitratine $\left(\mathrm{NaNO}_{3}\right)$, and sodium nitrite $\left(\mathrm{NaNO}_{2}\right)$. The potassium phase appears to be potassium carbonate, although that could not be confirmed.

Samples 2AY-12-ANU3, 2AY-12-ANU3A, and 2AY-12-ANU5 also consisted of varying proportions of rust/scale and tank waste salts (primarily natrite/thermonatrite $\left(\mathrm{Na}_{2} \mathrm{CO}_{3} \bullet \mathrm{nH}_{2} \mathrm{O}\right)$, nitratine $\left(\mathrm{NaNO}_{3}\right)$, and sodium nitrite $\left(\mathrm{NaNO}_{2}\right)$. Sample $2 \mathrm{AY}-12-\mathrm{ANU} 3 \mathrm{~A}$ shows evidence that it has been subjected to heating. Anhydrous natrite is present instead of thermonatrite. The XRD data suggests that the natrophosphate has partially decomposed. The potassium phase was largely absent from these samples.

Sample 2AY-12-ANU5A consisted largely of rust, with a trace of a sodium-rich phase that could not be further identified. The sample had no detectible radioactive counts associated with it.

\section{REFERENCES}

ATS-LT-161-100, Rev. F-0, “222-S Laboratory Sample Preparation and Operating Procedure for Scanning Electron Microscopes," Washington River Protection Solutions LLC, Richland, Washington.

ATS-LT-507-101, Rev. I-0, “222-S Laboratory X-Ray Diffractometry (XRD),” Washington River Protection Solutions LLC, Richland, Washington.

ATS-LT-519-107, Rev. F-1, “222-S Laboratory Polarized Light Microscopy,” Washington River Protection Solutions LLC, Richland, Washington.

RPP-PLAN-53352, 2012, Tank 241-AY-102 Annulus Sampling and Analysis Plan, Washington River Protection Solutions LLC, Richland, Washington. 


\section{LAB-RPT-12-00010 Rev. 0}

RPP-RPT-44630, 2012, Derivation of Best-Basis Inventory for Tank 241-AY-102 as of January 1, 2012, Rev. 3, Washington River Protection Solutions LLC, Richland, Washington.

RPP-RPT-53511, 2012, Final Report for Tank 241-AY-102 Annulus Solid Sample Taken in August, 2012, Rev. 0, Washington River Protection Solutions LLC, Richland, Washington.

RPP-RPT-54071,2012, Final Report for Tank 241-AY-102 Annulus, Rev. 0, Washington River Protection Solutions LLC, Richland, Washington. 
LAB-RPT-12-00010 Rev. 0

Appendix A

SAMPLE BREAKDOWN DIAGRAMS 
LAB-RPT-12-00010 Rev. 0

Appendix A

\begin{tabular}{|c|c|c|c|c|}
\hline \multicolumn{5}{|c|}{$\begin{array}{l}\text { Customer: Non-TCD } \backslash \text { Research } \\
\text { Project: AY102 Residual Samples } \\
\text { SDG: } 20121249 \\
\text { Charge Code: } 2 \text { A.19 }\end{array}$} \\
\hline \multirow{2}{*}{\multicolumn{5}{|c|}{$\begin{array}{c}\text { Matrix = Each } \\
\text { Client ID: AY102Annulus-1 }\end{array}$}} \\
\hline & & & & \\
\hline \multicolumn{5}{|c|}{ Tastemeses } \\
\hline \multicolumn{5}{|c|}{$\begin{array}{l}\text { S12R000482 } \\
\text { Sample Tracking }\end{array}$} \\
\hline \multirow{3}{*}{$\begin{array}{l}\text { During the digestions, } \\
\text { please note on bench sheet } \\
\text { whether solids are } \\
\text { completely digested. }\end{array}$} & 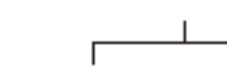 & 1 & $T$ & 7 \\
\hline & AY102Annulus-1-1 & AY102Amulus-1-2 & AY102Amulus-1-3 & AY102Amulus-1-4 \\
\hline & $\square$ & $\square$ & एक्य & एक \\
\hline \multirow{2}{*}{$\begin{array}{l}\text { For Environmental } \\
\text { digest, ash sample. }\end{array}$} & S12R000485 & $\begin{array}{l}\text { S12R000486 } \\
\text { HOLDPJC }\end{array}$ & S12R000487 & S12R000488 \\
\hline & PLM & & PLM & PLM \\
\hline \multirow[t]{2}{*}{$\begin{array}{l}\text { For GEA report Cs-137 } \\
\text { plus all above MDA }\end{array}$} & & $\sum_{\text {S12R000484 }}^{\substack{\text { Env } \\
\text { Acid } \\
\text { Digest }}}$ & & \\
\hline & & $\begin{array}{c}\text { GEA } \\
\text { Sr-90 } \\
\text { Americium } \\
\text { Plutonium }\end{array}$ & & \\
\hline
\end{tabular}


LAB-RPT-12-00010 Rev. 0

Appendix A

Customer: Non-TCD $\backslash$ Research

Project: AY102 Residual Samples

SDG: 20121523

Due Date:

Segment Number: 2AY-12-ANU1

Segment Portion: Grab Sample (Total)

Customer ID: 2AY-12-ANU1

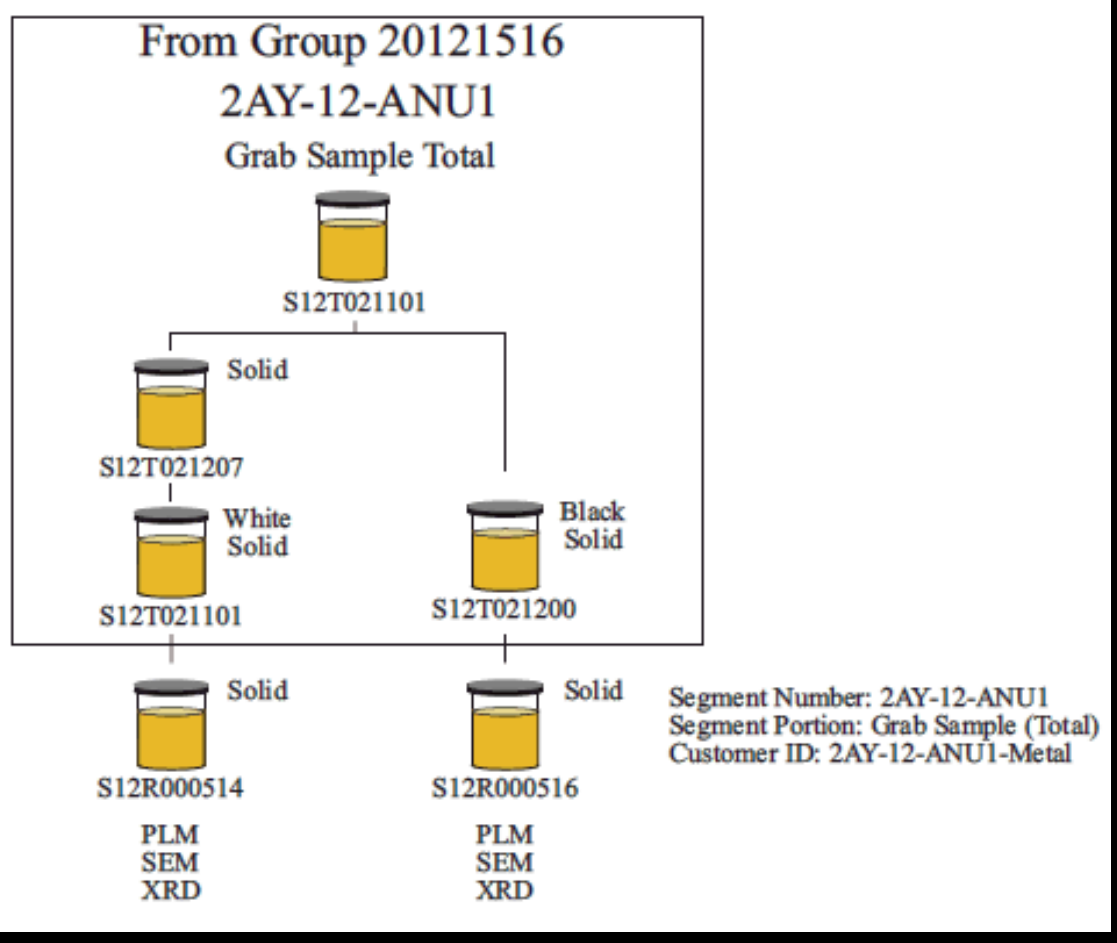

Customer: TCD/TCP

Project: AY102 Annulus APD

SDG: 20121589

Air Slot - Bulk

Due Date: 12-10-12

From Group 20121555

TSCA Regulated for PCB

Riser:90

Segment Number: 2AY-12-ANU3

Segment Portion: Grab Sample (Total)

Customer ID: Air Slot - Bulk

\section{AY-12-ANU3}

Grab Sample Total

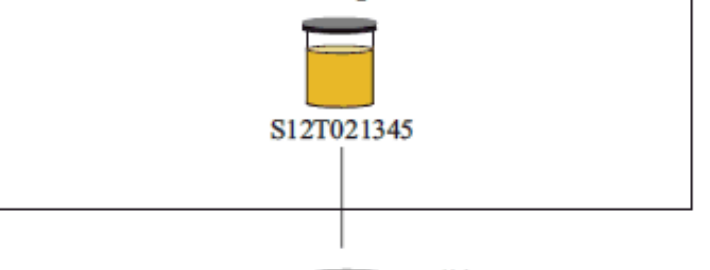

Solid $\begin{aligned} & \text { Note: Parent sample consisted of both white and } \\ & \text { dark colored grains. White grains were hand picked } \\ & \text { during subsampling. }\end{aligned}$
PLM
SEM
XRD


LAB-RPT-12-00010 Rev. 0

Appendix A

Customer: Non-TCD $\backslash$ Research

Project: AY102 Annulus APD

SDG: 20121589

Mound Sample - Bulk

Due Date: $12-10-12$

From Group 20121555

TSCA Regulated for PCB

Riser: 90

Segment Number: 2AY-12-ANU5

Segment Portion: Grab Sample (Total)

Customer ID: Mound - Bulk

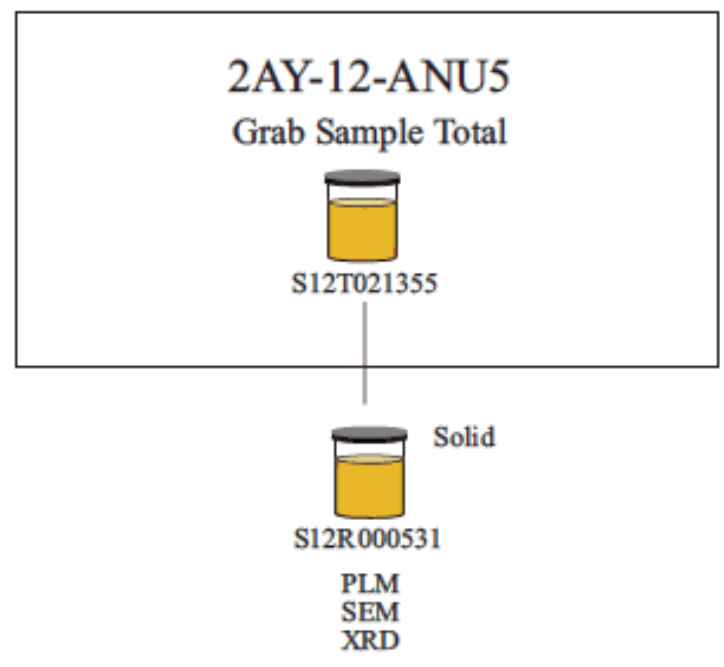

Customer: TCD/TCP

Project: AY102 Annulus APD

SDG: 20121589

Air Slot - Bulk A

Due Date: 12-10-12

From Group 20121555

TSCA Regulated for PCB

Riser:90

Segment Number: 2AY-12-ANU3A

Segment Portion: Grab Sample (Total)

Customer ID: Air Slot - Bulk A

2AY-12-ANU3A

Grab Sample Total

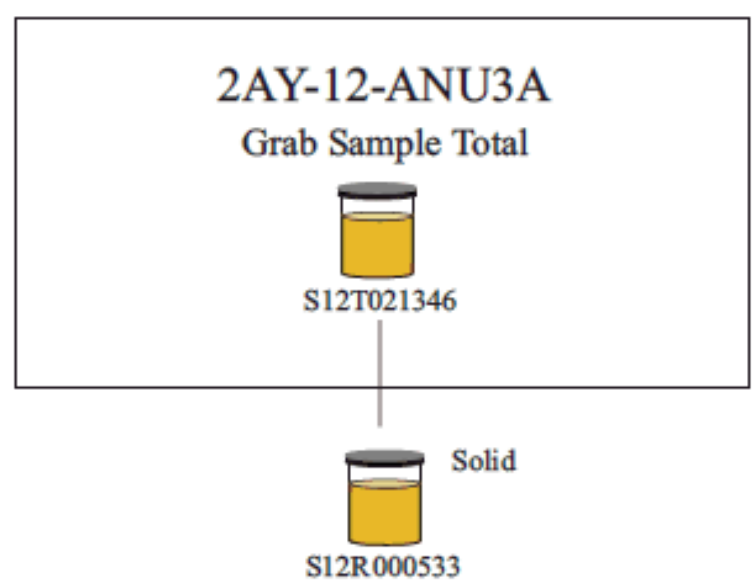

Dose Hot Cell

Sample Amount - HC

PLM

SEM

XRD

Solid Sp-G (APD) 
LAB-RPT-12-00010 Rev. 0

Appendix A

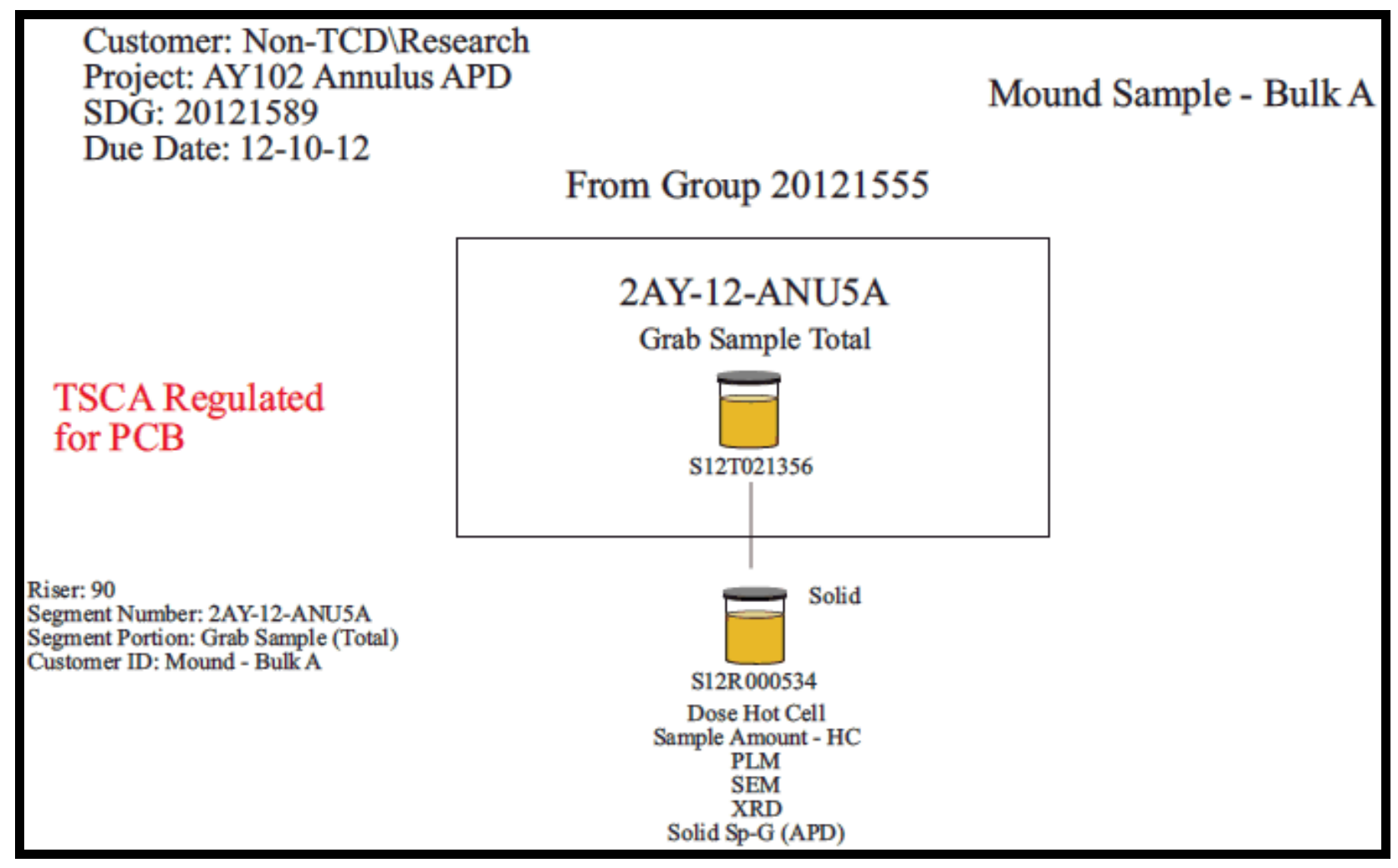




\section{Electronically Approved by:}

UserName: Cooke, Gary (h0410221)

Title: APD Chemist

Date: Thursday, 17 January 2013, 01:23 PM Pacific Time

Meaning: Approved by the author or delegate

UserName: Harrington, Stephanie (h4694341)

Title:

Date: Tuesday, 22 January 2013, 07:18 AM Pacific Time

Meaning: Approved by the customer or delegate

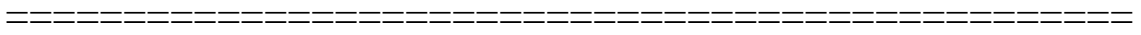

UserName: Hardy, Don (h0085161)

Title: Laboratory Facilities Manager

Date: Tuesday, 22 January 2013, 07:47 AM Pacific Time

Meaning: Approved by the Facility Manager or delegate

UserName: Seidel, Cary (h0009079)

Title: APD Manager

Date: Wednesday, 23 January 2013, 10:07 AM Pacific Time

Meaning: Approved by the Group Manager or delegate 
Distribution for LAB-RPT-12-00010

Cary M. Seidel

Don B. Hardy

Daniel L. Herting

John A. Pestovich

Heinz J. Huber

Jason S. Page

William S. Callaway

Stephanie J. Harrington R2-58

Dennis J. Washenfelder R2-53

Chelsea L. Rosenkrance R2-53

Ted J. Venetz

Terry L. Sams

Jacob G. Reynolds

N. W. Kirch

J. H. Rasmussen

D. M. Nguyen

K. D. Boomer

W. J. Powell

A.M. Templeton
R2-53

R2-52

R2-58

R2-58

R2-58

R2-58

R2-53

T6-14

T6-14

T6-05

T6-05

T6-05

T6-05

T6-05

R2-58

R2-58 